RFP-1704

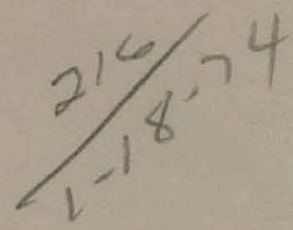

December 13, 1973
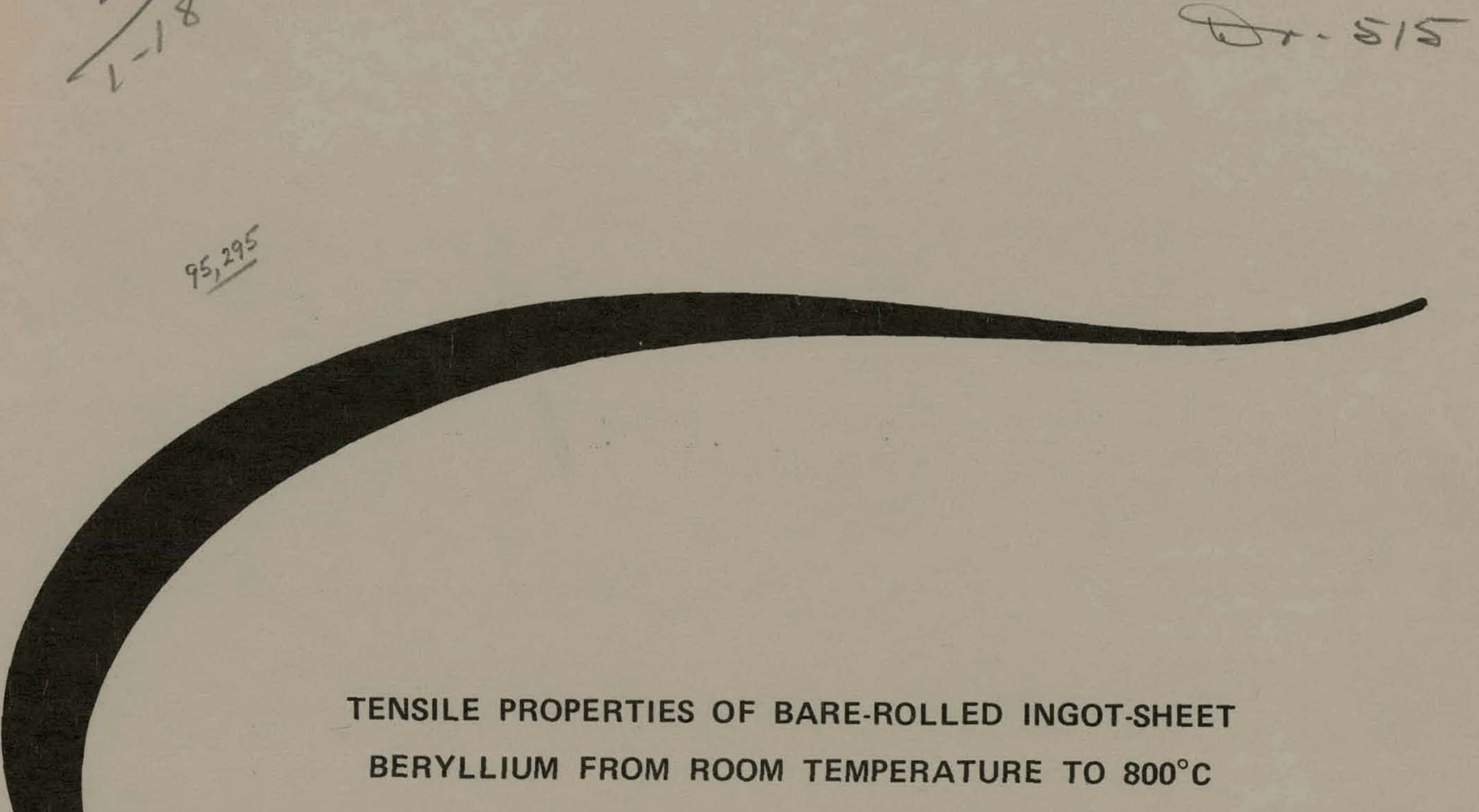

Delmar V. Miley

Ronald P. Brugger

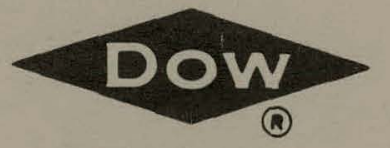

DOW CHEMICAL U.S.A.

ROCKY FLATS DIVISION

P. O. BOX 888

GOLDEN, COLORADO 80401

U. S. ATOMIC ENERGY COMMISSION

CONTRACT AT(29-1)-1106 


\section{DISCLAIMER}

This report was prepared as an account of work sponsored by an agency of the United States Government. Neither the United States Government nor any agency Thereof, nor any of their employees, makes any warranty, express or implied, or assumes any legal liability or responsibility for the accuracy, completeness, or usefulness of any information, apparatus, product, or process disclosed, or represents that its use would not infringe privately owned rights. Reference herein to any specific commercial product, process, or service by trade name, trademark, manufacturer, or otherwise does not necessarily constitute or imply its endorsement, recommendation, or favoring by the United States Government or any agency thereof. The views and opinions of authors expressed herein do not necessarily state or reflect those of the United States Government or any agency thereof. 


\section{DISCLAIMER}

Portions of this document may be illegible in electronic image products. Images are produced from the best available original document. 


\section{LEGAL NOTICE}

This report was prepared as an account of work sponsored by the United States Government. Neither the United States nor the Uniled States Atomic Energy Commission, nor any of their employees, nor any of their contractors, subcontractors, or their employees, makes any warranty, expressed or implied, or assumes any legal liability or responsibility for the accuracy, completeness or usefulness of any information, apparatus, product or process disclosed, or represents that its use would not infringe privately owned rights.

Printed in the United States of America

Available from the

National Technical Information Service

U. S. Department of Commerce

Springfield, Virginia 22151

Price: Printed Copy $\$ 4.00$ Microfiche $\$ 1.45$ 


\section{TENSILE PROPERTIES OF BARE-ROLLED INGOT-SHEET \\ BERYLLIUM FROM ROOM TEMPERATURE TO $800^{\circ} \mathrm{C}$}

Delmar. V. Miley

Ronald P." Brugger.

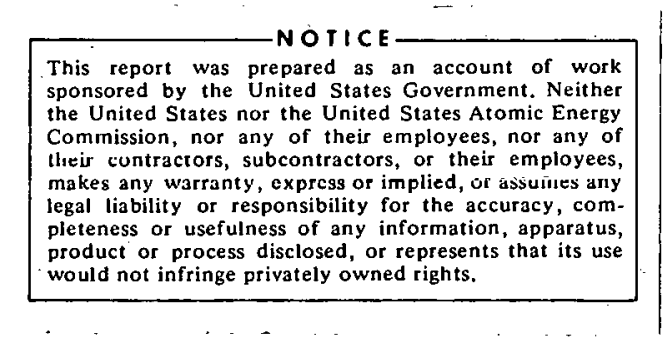

DOW CHEMICAL U.S.A.

ROCKY FLATS DIVISION

P. O. $B O \times 888$

GOLDEN, COLORADO 80401

Prepared under Contract AT(29-1)-1106

for the

Albuquerque Operations Office

U. S. Atomic Energy Commission

\section{SUBJECT DESCRIPTORS}

Tensile properties

Metallography

Strain hardening

Fracture mode

High temperature tests

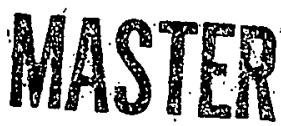


RFP-1704 


\section{CONTENTS}

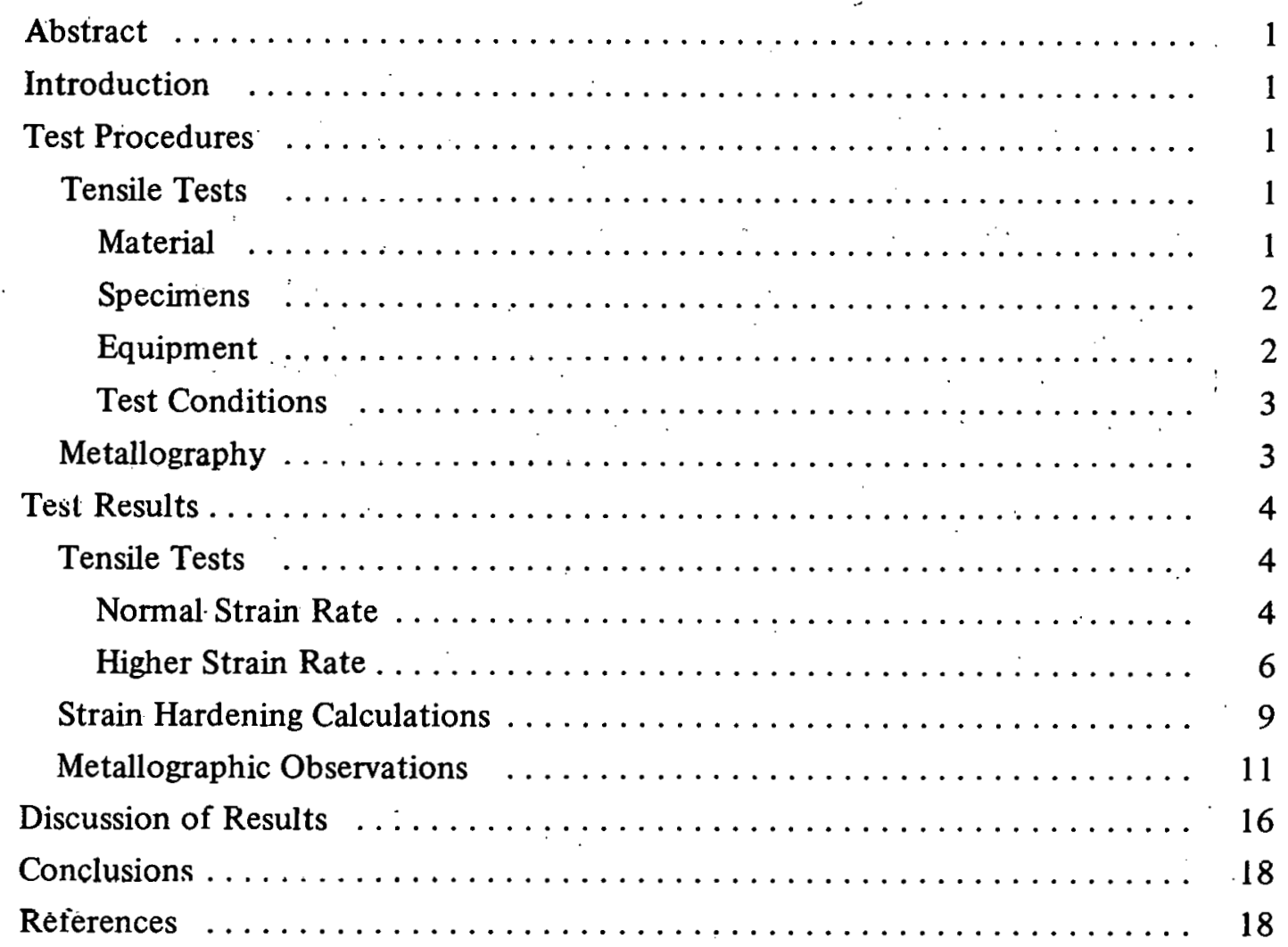




\section{ACKNOWLEDGMENTS}

The authors are indebted to a number of people who contributed to this work. They include W. W. Leslie, for his efforts in obtaining material and providing valuable information; R. F. Biela and B. F. Duesterbeck for machining; D. R. Floyd and A. E. Calabra for many helpful discussions and suggestions; and W. $\mathrm{H}$. Schmalhorst and S. Beitscher for their critical review of the manuscript. Their contributions are greatly appreciated. 


\title{
TENSILE PROPERTIES OF BARE-ROLLED INGOT-SHEET BERYLLIUM FROM ROOM TEMPERATURE TO $800^{\circ} \mathrm{C}$
}

\author{
Delmar V. Miley and Ronald P. Brugger
}

\begin{abstract}
Tensile properties of bare-rolled ingotsheet beryllium from room temperature to $800^{\circ} \mathrm{C}$ are reported. While strength values show a steady decrease above room temperature, tensile elongations exhibit peaks at approximately 300 and $700^{\circ} \mathrm{C}$. The strain hardening exponent varies with temperature and amount of strain, and ranges between approximately 0.10 and 0.26 . Metallographic examinations reveal cleavage fracture at the lower temperatures, accompanied by severe grain deformation above room temperature. This is followed by a temperature range in which ductile rupture occurs, and finally, at the higher temperatures, grain boundary failure. The low $\mathrm{BeO}$ content of this material and the post-rolling heat treatment given to the sheet are factors which improve the high temperature ductility as compared to other grades of beryllium.
\end{abstract}

\section{INTRODUCTION}

Dcvclopment work al Rocky Flats over the past several years has resulted in a process for the conversion of scrap beryllium into a cast ingot which can be subsequently rolled into sheet and deep drawn into parts. ${ }^{1}$ For some applications, ingotsheet beryllium offers economic and fabrication advantages over powder-source beryllium.

Two forms of ingot-sheet are produced. Canrolled material results from rolling a billet which has been clad in stainless steel. Thickness of canrolled sheet is on the order of $1 / 4$ inch. Can-rolled sheet can be further reduced in thickness by barerolling to $0.100 \mathrm{in}$. or less. Bare-rolled sheet normally has greater strength and ductility than can-rolled sheet. $^{2-4}$

Several recent Rocky Flats publications ${ }^{2-5}$ describe some mechanical properties that have been determined for ingot-sheet beryllium. In two reports, Beitscher ${ }^{2,3}$ detailed the tensile properties of canrolled sheet from -196 to $700^{\circ} \mathrm{C}$. Tensile properties of can-rolled sheet, bare-rolled sheet and formed parts were reported by Miley and Brugger. ${ }^{4}$ Bending fatigue characteristics of can-rolled material were also investigated. ${ }^{5}$

Much of the early work on ingot-source beryllium was done on can-rolled material. Bare-rolled sheet offers the advantages of higher strength and ductility, and for most applications would probably be the preferred material to use.

This study was therefore undertaken to better characterize bare-rolled ingot-source beryllium, and will present the tensile properties and fracture behavior from room temperature to $800^{\circ} \mathrm{C}$.

\section{TEST PROCEDURES}

\section{Tensile Tests}

$\underline{\text { Material }}$

The beryllium used for this investigation came from one bare-rolled sheet measuring approximately 17 by 50 by 0.100 inch: The production of this material starts by vacuum induction casting of scrap beryllium into a 9 - by 9 - by 20 -in. ingot. The ingot is cut into billets that are then clad in stainless steel for the "can rolling" step. A 21pass schedule is used, with a starting temperature of $1040^{\circ} \mathrm{C}$ and a finishing temperature of $760^{\circ} \mathrm{C}$. The resulting can-rolled sheet is approximatèly 0.2 -in. thick.

The cladding material is removed, and the beryllium sheet is bare-rolled at $730^{\circ} \mathrm{C}$. A five-pass schedule is used, with 45 -minute anneals at $760^{\circ} \mathrm{C}$ after each pass. Nominal thickness of the final sheet is 0.1 inch.

The bare-rolled sheet is given a 9-hour vacuum anneal at $760^{\circ} \mathrm{C}$, followed by a 16 -hour furnace cool. 
Chemical analysis of the sheet is presented in

Table 1 .

$\underline{\text { Specimens }}$

The beryllium sheet was cut into eleven equal strips, each measuring approximately 4 by 17 in., and each strip was given a letter designation. Significant variations in properties throughout the sheet would be detected if they were present. Each of eight strips yielded 14 longitudinal specimens (parallel to the final rolling direction), and the other three strips each yielded 12 transverse specimens (transverse to the final rolling direction).

The specimen design is shown in Figure 1. This is the standard pin-loaded specimen in use at Rocky Flats for most beryllium testing. Specimen bianks were removed from the sheet by hot punching at approximately $600^{\circ} \mathrm{C}$. This temperature is well below the annealing temperature used after rolling, and has no effect on properties. This was confirmed by tensile tests when the hot-punching operation was first incorporated. Final size and shape were achieved by tracer milling;. using decreasing depth of cuts to reduce machining damage. Past experience has shown that machining of the thickness dimension is not necessary for bare-rolled material.

Prior to testing, all specimens were etched in an aqueous solution containing 20-parts nitric acid and 2-parts hydrofluoric acid. Approximately 0.005 in. of material was removed from each surface. This is the recommended procedure ${ }^{6}$ for removal of machining damage which drastically reduces ultimate strength and elongation. The need to etch beryllium after machining had been determined from previous investigations. ${ }^{2-4}$

Table 1. Chemical Analysis of Beryllium Sheet 502041-B. (wt\%)

$\begin{array}{lcll}\mathrm{Be} & 99.68 & \mathrm{BeO} & <0.010 \\ \mathrm{Al} & 0.070 & \mathrm{Ca} & <0.003 \\ \mathrm{Fe} & 0.149 & \mathrm{Cd} & <0.001 \\ \mathrm{Si} & 0.050 & \mathrm{Co} & <0.001 \\ \mathrm{C} & 0.073 & \mathrm{Mg} & <0.001 \\ \mathrm{~N} & 0.004 & \mathrm{Mo} & <0.003 \\ \mathrm{Cr} & 0.008 & \mathrm{~Pb} & <0.001 \\ \mathrm{Cu} & 0.008 & \mathrm{Zn} & <0.010 \\ \mathrm{Mn} & 0.010 & \mathrm{~W} & <0.010 \\ \mathrm{Ni} & 0.016 & & \\ \mathrm{Ti} & 0.036 & & \end{array}$

Equipment

Elevated temperature tensile tests were performed on an Instron Model TT-D-L testing machine (Instron Corporation, Canton, Massachusetts). The temperature and vacuum environment was achieved with a Satec Model VC-206-T vacuum furnace (Satec Systems, Inc., Grove City, Pennsylvania). The complete furnace system is track-mounted so the furnace can be positioned between the crossheads of the Instron testing machine for high temperature testing, and then be moved to allow for room-temperature testing.

Strain measurements were accomplished in three ways:

1. For some room-lemperaluic tests an Instron strain gage extensometer, which was attached to the sample, drove the recording chart.

2. Other room-temperature tests and some of the high-temperature tests were conducted with a Satec LVDT type extensometer, which.required matching electronics for connection to the Instron recorder chart drive. This

Figure 1. Pin-Loaded Tensile Specimen for Beryllium Sheet.

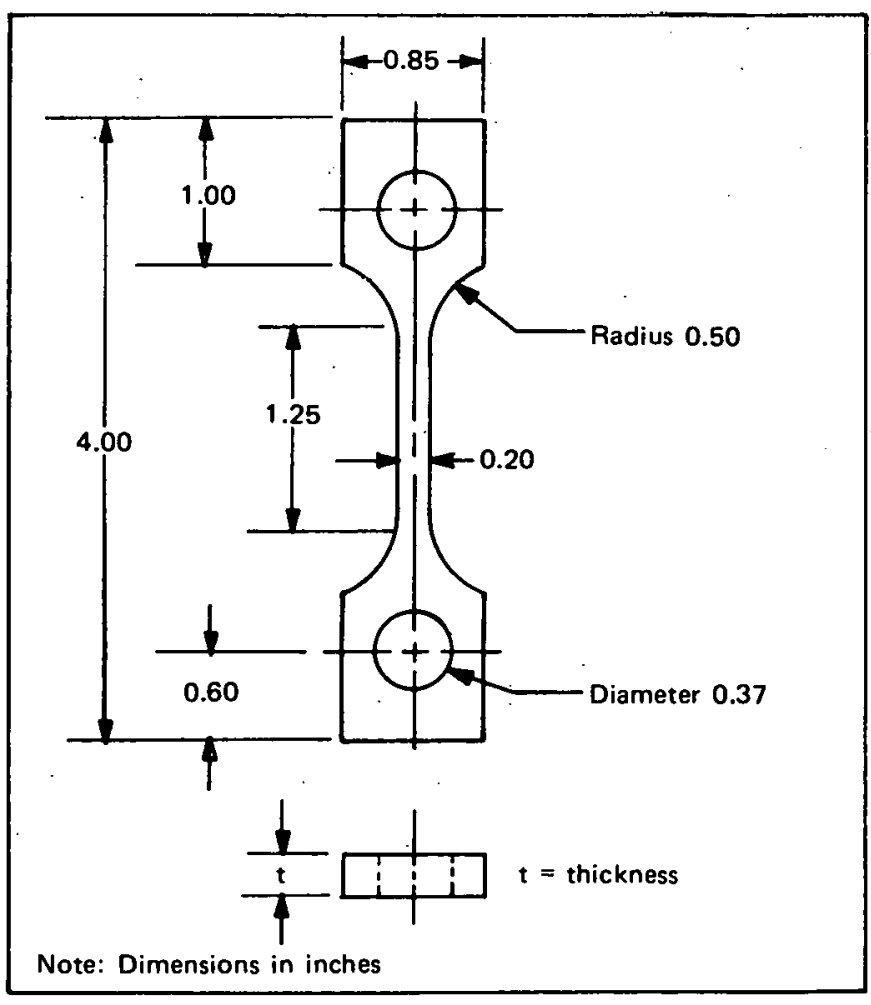


instrument has a linear range of $0.2 \mathrm{in}$. at the 100:1 magnification ratio, and a linear range of $0.5 \mathrm{in}$. at $50: 1$.

3. When specimen elongations exceeded these ranges, it was necessary to use a synchronous driven recording chart for the entire test.

$\underline{\text { Test Conditions }}$

Comparative tests were conducted at room temperature using the standard, room-temperature setup and the high-temperature setup. Average results for the different setups, and the average for all tests, showed standard deviations of 1.0 or less; indicating that the extra fixturing required for the high-temperature tests would not adversely affect accuracy or reproducibility.

The temperature gradient within the furnace was determined with a dummy beryllium specimen that had been drilled to accept shielded thermocouples at the top, middle; and bottom of the test . section. Chromel-Alumel thermocouples with a limit of error of $\pm 3 / 4 \%$ were used. The readings indicated that the desired test temperatures could be maintained within $\pm 5^{\circ} \mathrm{C}$, and that the gradient along the test section was within $\pm 2^{\circ} \mathrm{C}$. On the basis of these preliminary tests, it was decided to use only one thermocouple in contact with the center of the specimen for the tensile tests. When the desired temperature for each test was reached, the system was allowed to equilibrate for 15 minutes prior to applying the load. The system was maintained at approximately $10^{-5}$ torr during heat-up and testing.

All tests were performed at constant crosshead speeds. The "normal" strain rate tests were run at 0.05 -in. per minute. This results in a strain rate of approximately $0.005 \mathrm{in}$./in. min calculated for the elastic portion of the curve at room temperature. This is the recommended strain rate for testing beryllium. ${ }^{6}$ For the "high" strain rate tests, the crosshead speed was increased by a factor of 10 to 0.5 -in: per minute:

Ultimate and $0.2 \%$ yield loads were determined from the load-strain curves for each test. Elongations were measured from the load-strain curves for tests in which the extensometer was attached for the duration of the test. These results were compared to elongations calculated from gage marks on the same samples. The two methods were in agreement. Elongations of samples tested without an extensometer were measured by the gage-mark technique. Reduction in area values were calculated from micrometer measurements of the smallest cross section before and after the test.

Data from the load-elongation curves were also used to calculate strength coefficient and strain hardening exponent at the various test temperatures. These values can then be used in an equation of the form

$$
S=A e^{n}
$$

to describe the plastic behavior of the material up to maximum load. ${ }^{7}$ For this equation:

$$
\begin{aligned}
& \mathrm{S}=\text { true stress } \\
& \mathrm{e}=\text { plastic } \text { strain } \\
& \mathrm{A}=\text { strength coefficient } \\
& \mathrm{n}=\text { strain hardening exponent }
\end{aligned}
$$

A computer program devised by Beitscher and Doyle $^{8}$ was used to calculate $A$ and $n$.

\section{Metallography}

Metallographic examinations were conducted on many of the tensile specimens after failure. Samples were mounted using a technique described in reference 9. Sample preparation was similar to that previously reported ${ }^{10}$ for ingot-sheet beryllium, but slight modifications to the technique were used to reduce sample pitting. The normal procedure of etching the beryllium with $10 \%$ sulfuric acid after each grinding step was omitted. Etching after each polishing step with $2 \%$ hydrofluoric acid in ethanol was also eliminated. The elimination of the etching steps necessitated greater care in performing the mechanical grinding and polishing steps. 
The worst sample pitting occurred during final vibratory polishing, using a water slurry of 0.05 micron alumina and a small amount of chromic acid. Pitting was avoided by eliminating the water slurry. An acceptable final polish was obtained by long-term vibratory polishing on $1 / 4$-micron diamond, or by vibratory polishing on a slurry of 0.05-micron alumina in Metadi Fluid (Buehler Ltd.).

Both bright field and polarized illumination were used to examine the as-polished specimens. Bright field revealed inclusions, shape of voids, and other. features not requiring grain structure for observations. Polarized illumination revealed the grain structure.

\section{TEST RESULTS}

\section{Tensile Tests}

\section{Normal Strain Rate}

The data for tensile tests conducted at the normal strain rate (crosshead speed of 0.05-in. per min) are summarized in Table 2 and Figures 2 and 3.
Table 2 presents the mean values, standard deviation, and range of values of the tensile properties for each test temperature. The mean values for the longitudinal test specimens are plotted on the two figures.

As shown in Figure 2, ultimate strength for longitudinal specimens at room temperature averaged over 50,000 psi. Between room temperature and $400^{\circ} \mathrm{C}$, the strength decreased approximately $50 \%$; then it showed a slight decrease between 400 and $600^{\circ} \mathrm{C}$. Above $600^{\circ} \mathrm{C}$, the strength reduction again became quite marked; at $800^{\circ} \mathrm{C}$ the ultimate was 3000 psi.

The yield-strength curve shows a similar shape. Up to $600^{\circ} \mathrm{C}$, the yield strength is about 48 to $58 \%$ of the ultimale slieingth. Above $600^{\circ} \mathrm{G}$, the yield strength is 70 to $80 \%$ of ultimate.

Percent elongation and percent reduction in area are presented as the measures of tensile ductility in Figure 3. The elongation curve shows a maximum of almost $60 \%$ at $300^{\circ} \mathrm{C}$; drops to $35 \%$ at $500^{\circ} \mathrm{C}$; and goes through a second maximum of almost $80 \%$ near $700^{\circ} \mathrm{C}$. The reduction in area

Table 2. Tensile Properties of Bare-Rolled Beryllium; Room Temperature to $800^{\circ} \mathrm{C}$.

Longitudinal Specimens

\begin{tabular}{|c|c|c|c|}
\hline \multirow{2}{*}{$\begin{array}{c}\text { Test } \\
\text { Temp }\left({ }^{\circ} \mathrm{C}\right)\end{array}$} & \multicolumn{3}{|c|}{ UTS (ksi) } \\
\hline & $\overline{\text { Mean }}$ & S.D. & Range \\
\hline Room Temp. & 52.7 & 0.9 & $51.3-53.3$ \\
\hline 100 & 48.8 & 1.5 & $46.7-50.2$ \\
\hline 150 & 44.6 & 1.2 & $42.9-45.6$ \\
\hline 200 & 42.9 & 2.4 & $39.7-45.3$ \\
\hline 250 & 35.5 & 1.2 & $34.3-36.5$ \\
\hline 300 & 31.2 & 0.7 & $30.6-32.1$ \\
\hline 350 & 27.4 & 0.2 & $27.2-27.8$ \\
\hline 400 & 24.5 & 0.2 & $24.2-24.7$ \\
\hline 450 & 23.2 & 0.3 & $23.0-23.6$ \\
\hline 500 & 22.5 & 0.5 & $21.8-23.0$ \\
\hline 550 & 21.8 & 0.2 & $21.6-22.0$ \\
\hline 600 & 20.5 & 0.6 & $19.8-21.1$ \\
\hline 650 & 14.7 & 0.3 & 14.4-15.1 \\
\hline 700 & 7.9 & 0.1 & $7.8-8.1$ \\
\hline 750 & 4.5 & 0.1 & $4.4-4.6$ \\
\hline 800 & 3.0 & 0.1 & $2.8-3.1$ \\
\hline
\end{tabular}

\begin{tabular}{|c|c|c|}
\hline \multicolumn{3}{|c|}{$0.2 \%$ YS (ksi) } \\
\hline Mean & S.D. & Range \\
\hline 25.4 & 0.4 & $25.0-25.9$ \\
\hline 23.7 & 0.7 & $22.7-24.1$ \\
\hline 21.6 & 0.8 & $20.4 \cdot 22.2$ \\
\hline 22.0 & 1.1 & $20.7-23.1$ \\
\hline 18.3 & 0.6 & $17.5-18.9$ \\
\hline 17.3 & 0.5 & $16.9-18.0$ \\
\hline 15.7 & 0.6 & $15.0-16.5$ \\
\hline 13.8 & 0.4 & $13.4-14.2$ \\
\hline 13.4 & 0.2 & $13.1-13.6$ \\
\hline 12.8 & 0.5 & $12.1-13.2$ \\
\hline 12.5 & 0.3 & $12.0-12.8$ \\
\hline 11.5 & 0.7 & $10.6-11.4$ \\
\hline 9.8 & 0.3 & $9.5-10.1$ \\
\hline 6.1 & 0.2 & $5.8-6.2$ \\
\hline 3.6 & 0.1 & $3.5 \cdot 3.7$ \\
\hline 2.1 & 0.2 & $1.8-2.3$ \\
\hline
\end{tabular}
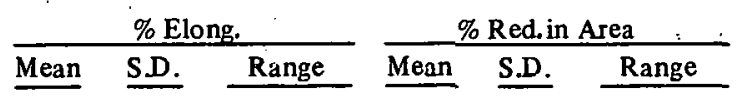
No. Tests

Transverse Specimens

$\begin{array}{crrr}\text { Room Temp. } & 49.8 & 0.5 & 49.6-50.6 \\ 200 & 39.2 & 1.2 & 38.0-40.9 \\ 400 & 23.7 & 0.1 & 23.6-23.9 \\ 600 & 20.0 & 0.4 & 19.6-20.4 \\ 800 & 2.9 & 0.1 & 28-3.0\end{array}$

$\begin{array}{rrr}25.7 & 0.6 & 25.2-26.4 \\ 21.7 & 1.2 & 20.5-23.2 \\ 14.5 & 0.5 & 14.0-15.1 \\ 12.2 & 0.1 & 12.1-12.4 \\ 2.1 & 0.2 & 1.8-2.3\end{array}$

$\begin{array}{rr}7.1 & 0.7 \\ 33.5 & 3.0 \\ 49.1 & 3.0 \\ 43.7 & 2.3 \\ 45.7 & 2.1\end{array}$

6.0-8.0

$11.6-18.4$

$23.2-33.2$

$28.4-44.8$

$46.0-54.8$

$55.6-58.8$

$49.2-61.6$

$49.6-55.2$

$35.6-41.2$

34.4-36.4

$38.4-41.2$

$41.2-55.6$

72.4-81.6

$70.0-84.4$

$67.2-69.2$

49.2-56.0

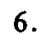

13.2

24.7

31.2

49.3

62.7

66.6

68.0

68.5

70.1

70.8

68.8

62.5

56.8

46.9

35.1

1.4

2.4

3.8

7.0

$3: 1$

1.1

1.2

0.9

1.6

2.0

1.1

1.8

4.8

1.8

1.1

2.4

$\begin{array}{rr}4.2-7.4 & 4 \\ 9.9-15.6 & 4 \\ 19.0-26.8 & 4 \\ 22.2-40.1 & 5 \\ 45.6-52.9 & 4 \\ 61.5-64.0 & 4 \\ 64.9-67.9 & 5 \\ 66.9-69.0 & 4 \\ 66.2-69.9 . & 4 \\ 67.9-72.1 & 4 \\ 69.3-72.1 & 4 \\ 67.2-71.2 & 5 \\ 57.3-68.8 & 4 \\ 54.1-59.1 & 5 \\ 45.7-48.2 & 4 \\ 31.8-37.5 & 4\end{array}$

6.4- 8.0 30.8-37.6 46.0-53.2 40.4-45.6 $43.2-48.0$

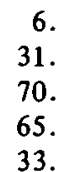

6.1
31.2
70.1
65.7
33.3

$\begin{array}{rr}0.5 & 5.3-6.4 \\ 3.5 & .27 .1-35.2 \\ 0.6 & : 69.3-70.6 \\ 4.8 & 61.5-70-5 \\ 2.3 & 30.5-36.1\end{array}$

\author{
. \\ (n)
}


values increase rapidly up to $300^{\circ} \mathrm{C}$; then level off at about 60 to $70 \%$ at $600^{\circ} \mathrm{C}$; then drop sharply again.

The inflections in the ductility curves correlate well with changes in fracture mode that were observed metallographically. This will be discussed more fully in a later section.

As mentioned, Figures 2 and 3 present the data for specimens from the longitudinal orientation. Specimens from the transverse orientation were tested only at five different temperatures to provide a spot-check comparison with longitudinal properties. At room temperature, the ultimate strength and elongation in the transverse direction are normally less than in the longitudinal direction, and yield strengths are the same. ${ }^{4}$ The sheet of material used for this investigation had slightly higher transverse elongation than normally expected. Ultimate strength was about 3000 psi lower than in the longitudinal direction. From Table 2; it can be seen that the transverse ultimate remains lower than the longitudinal ultimate up to about $400^{\circ} \mathrm{C}$, and from there on the two values are essentially equal. Yield strength and ductility values for both orientations are similar over the entire testing range.

Figure 2. Effect of Test Temperature on Tensile Strength of Bare-Rolled Beryllium (longitudinal specimens).

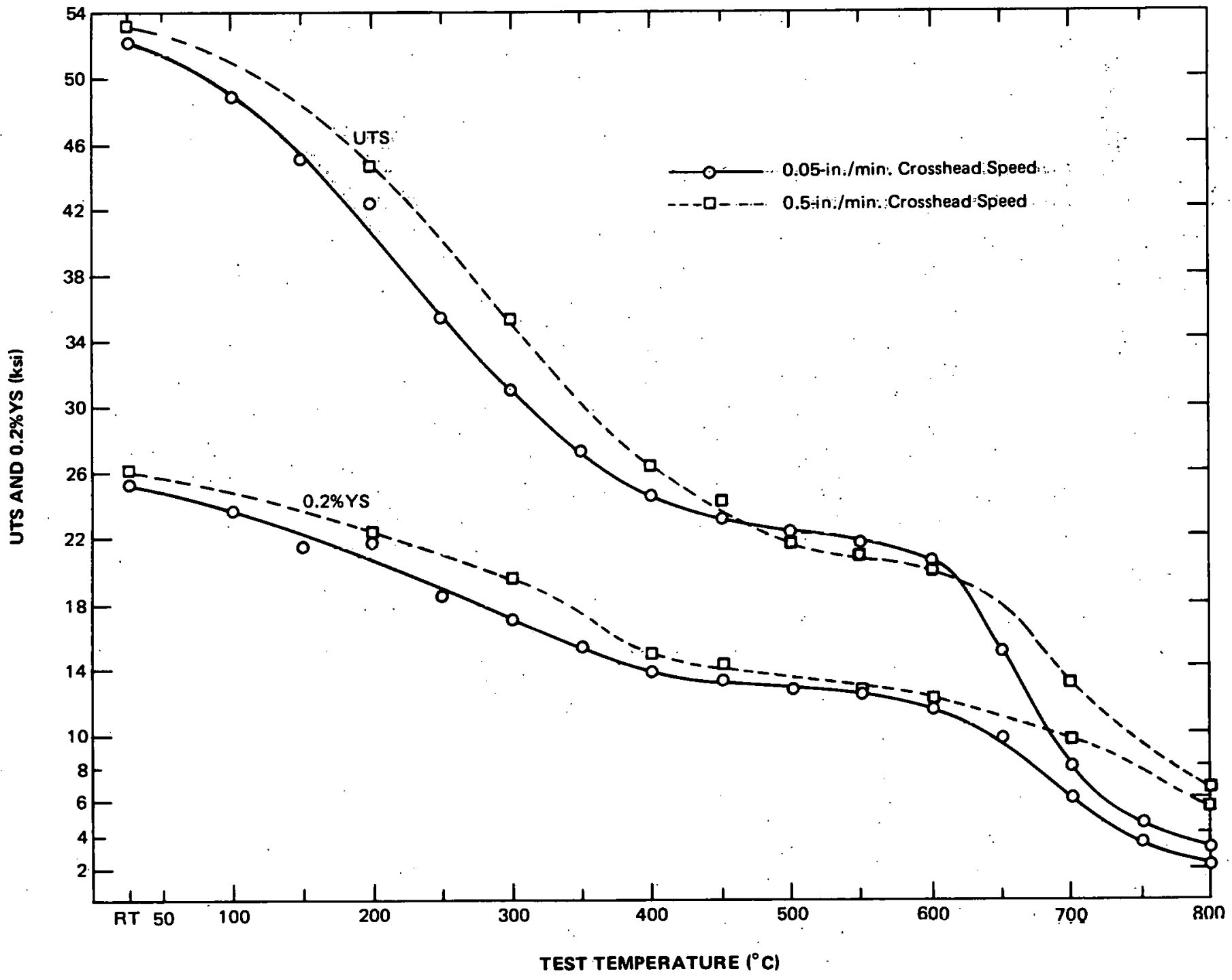




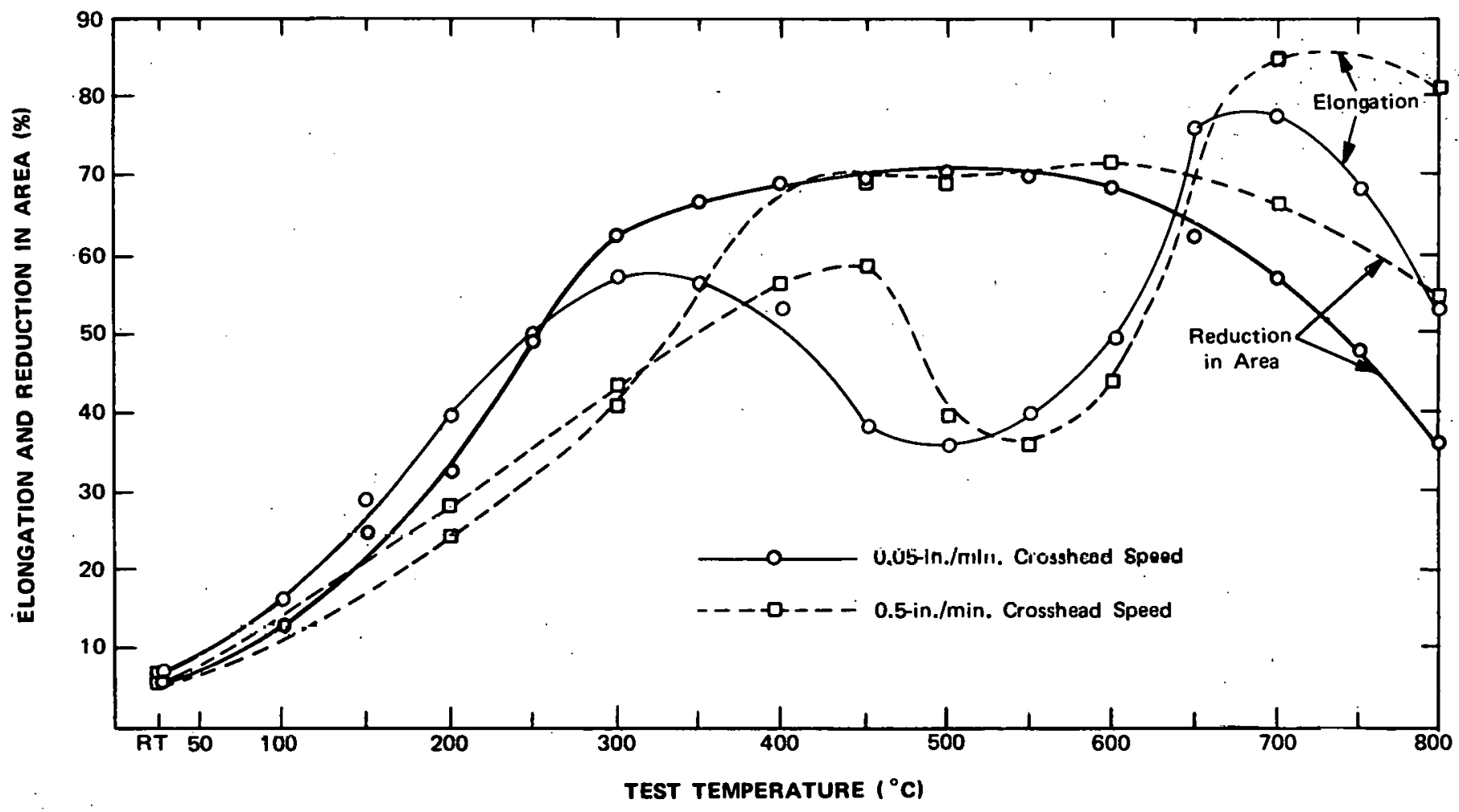

Figure 3. Effect of Test Temperature on Tensile Ductility of Bare-Rolled Beryllium (longitudinal specimens).

Table 3. Tensile Properties of Bare-Rolled Beryllium at Elevated Temperatures and Higher Strain Rate.*

\begin{tabular}{|c|c|c|c|c|c|c|c|c|c|c|c|c|c|c|}
\hline $\begin{array}{c}\text { Test } \\
\left.\text { Temp }{ }^{\circ} \mathrm{C}\right) \\
\end{array}$ & Orient. & \multicolumn{3}{|c|}{ UTS (ksi) } & \multicolumn{3}{|c|}{$0.2 \%$ YS (ksi) } & \multicolumn{3}{|c|}{ \%.Elong. } & \multicolumn{3}{|c|}{ \% Red. in Area } & $\begin{array}{l}\text { No. } \\
\text { Tests } \\
\end{array}$ \\
\hline R.T. & Long. & 53.2 & 0.4 & $52.8-53.6$ & 26.3 & 0.2 & $26.1-26.5$ & 5.0 & 0.2 & $4.8-5.2$ & 5.0 & $0 . \overline{7}$ & 4.3- 5.9 & 4 \\
\hline 300 & Trans. & 35.3 & 1.7 & $34.1-36.5$ & 19.8 & 0.5 & $19.4-20.1$ & 43.8 & 10.5 & $36.4-51.2$ & 41.2 & 10.9 & $33.5-48.9$ & 2 \\
\hline 400 & Long. & 26.3 & 0.2 & $25.9-26.4$ & 15.0 & 0.1 & $14.9-15.2$ & 56.5 & 5.6 & $51.2-64.4$ & 68.3 & 2.7 & $66.4-72.3$ & 4 \\
\hline 450 & Trans. & 24.2 & 0.9 & $23.5-24.8$ & 14.7 & 0.6 & $14.2-15.1$ & 58.0 & 7.4 & $52.8-63.2$ & 68.6 & 1.5 & $67.5-69.6$ & 2 \\
\hline 500 & Trans. & 21.6 & 0.2 & $21.4-21.7$ & 12.7 & 0.4 & $12.4-12.9$ & 39.2 & 5.1 & $35.6-42.8$ & 67.9 & 5.3 & $64.1-71.6$ & 2 \\
\hline 600 & Long. & 20.1 & 0.3 & $19.7-20.5$ & 12.0 & 0.4 & $11.4-12.3$ & 43.5 & 1.7 & $41.6-45.6$ & 71.6 & 0.9 & $70.6-72.5$ & 4 \\
\hline 700 & Trans. & 13.1 & 0.2 & $12.9-13.2$ & 9.7 & 0 & $9.7-9.7$. & 85.4 & 13.3 & $76.0-94.8$ & 66.1 & 8.1 & $60.3-71.8$ & 2 \\
\hline 800 & Long. & 6.6 & 0.1 & $6.5-6.7$ & 5.7 & 0.2 & $5.6-5.9$ & 81.1 & 11.9 & $68.8-92.8$ & 54.6 & 3.8 & $50.2-58.5$ & 4 \\
\hline
\end{tabular}

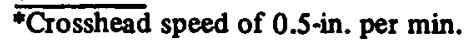

Both the longitudinal and transverse specimens exhibit slightly serrated load-strain curves at $400^{\circ} \mathrm{C}$. The amplitude of the serrations increases to a maximum at $550^{\circ} \mathrm{C}$, then drops again to light serrations at $600^{\circ} \mathrm{C}$. Between 600 and $800^{\circ} \mathrm{C}$, the amplitude of the serrations again increases, but only slightly. Figure 4 shows portions of serrated load-strain curves for several test temperatures.
Higher Strain Rate

Table 3 and Figures 2 and 3 show the data for tests conducted at the higher strain rate, using a crosshead speed of 0.5 -in. per min. While this speed is not sufficient to qualify as a true "high" strain rate, it does produce some changes in properties that are probably indicative of the effects 
RFP-1704

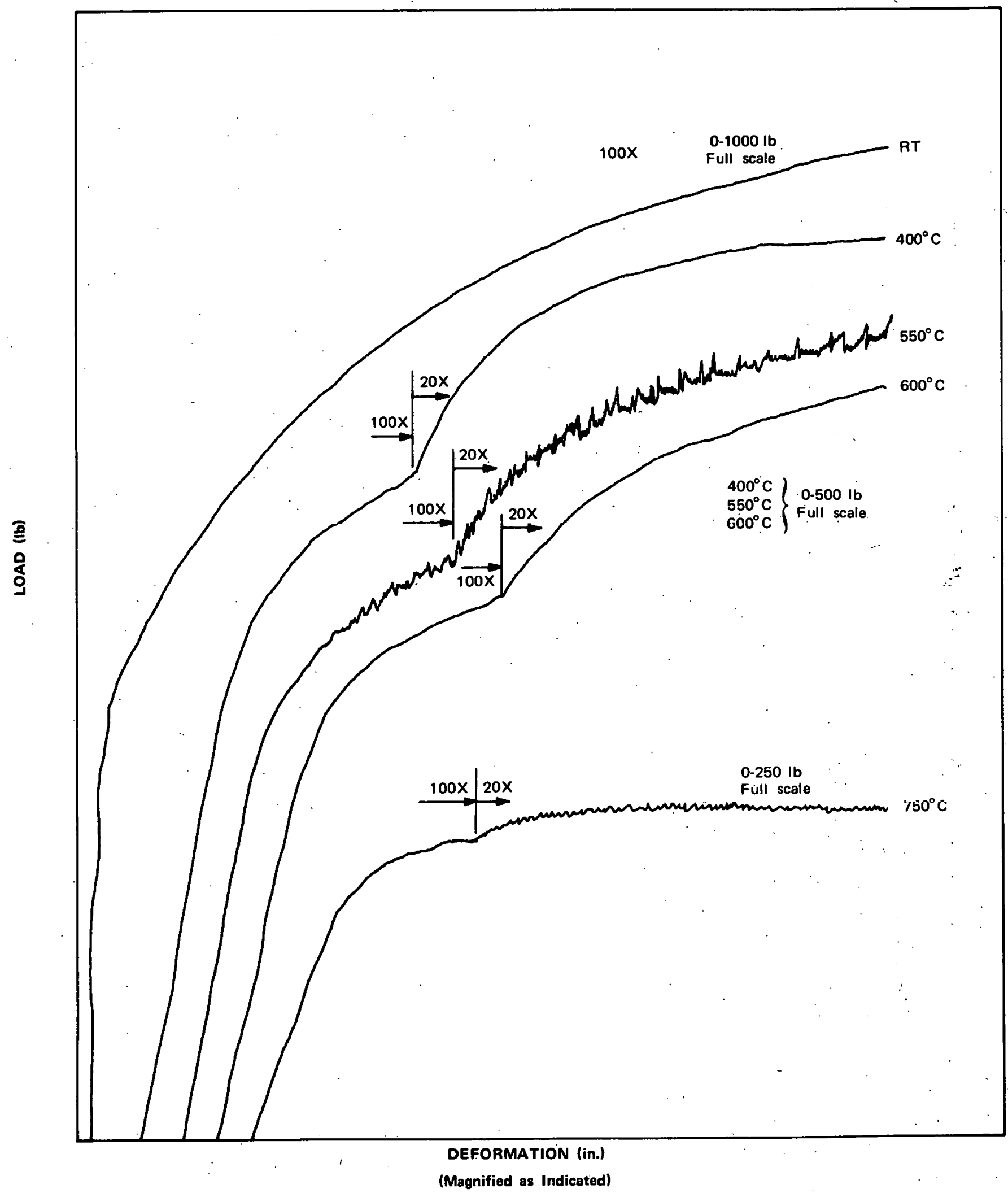

Figure 4. Portions of Load-Deformation Curves for $\mathbf{0 . 0 5}$-in./min. Tests. 


\section{RFP-1704}

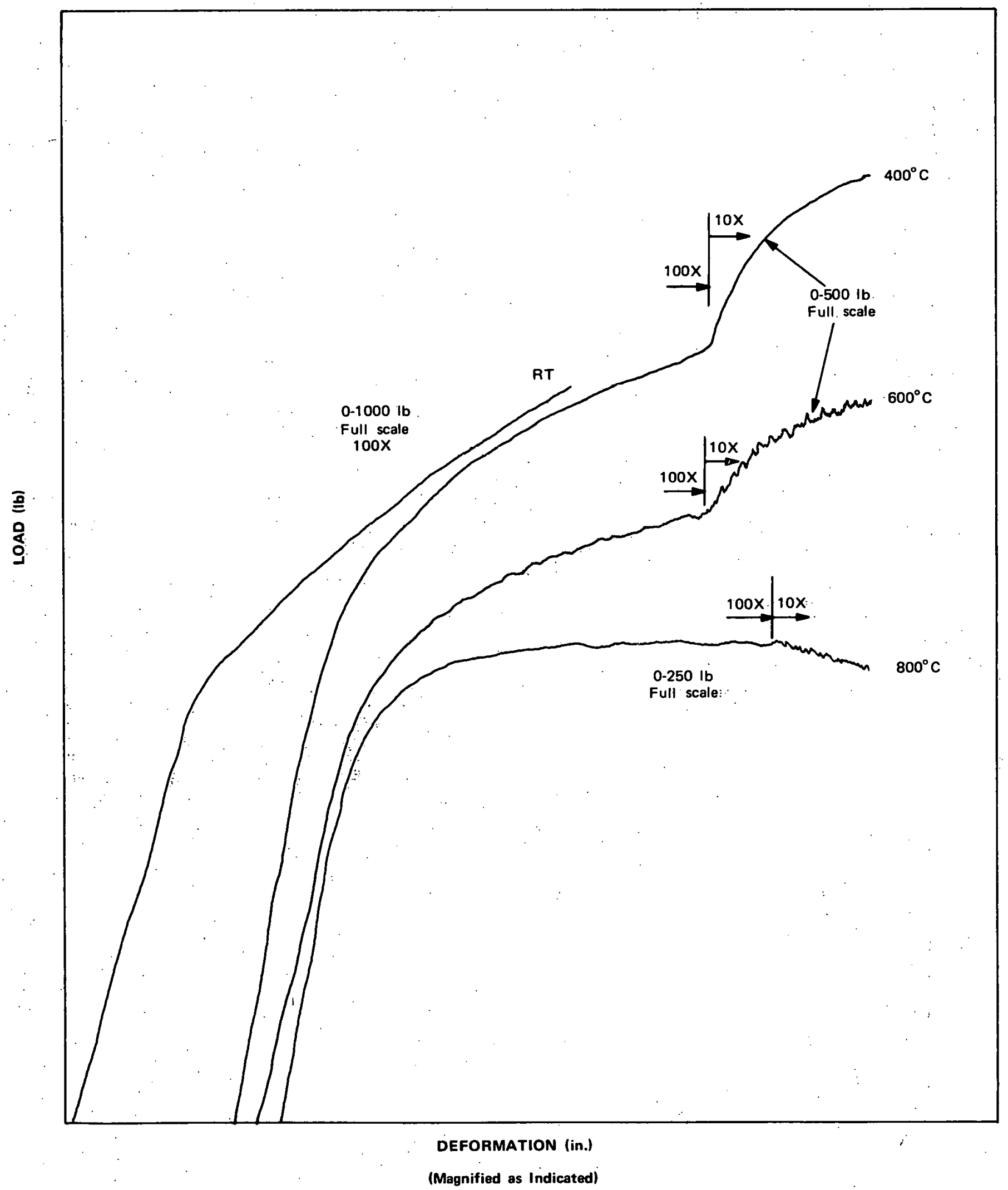

Figure 5. Portions of Load-Deformation Curves for 0.5 -in./min. Tests. 
that would be expected by continuing to increase the testing speed.

In Figure 2, the plots of ultimate and yield strength versus test temperature show the same general shape that was found for the normal strain rate tests. However, for a given temperature, the higher strain rate tests generally resulted in slightly higher strength values. In the 450 to $600^{\circ} \mathrm{C}$ range, strengths were . quite close for the two strain rates.

The tensile ductility curves, Figure 3, also maintain the same shape as the normal strain rate data. The effect of the higher strain rate was to shift the position of the peaks to slightly higher temperatures.

The occurrence of serrated load-strain curves at the higher strain rate closely parallels those for the normal strain rate tests. However, the amplitude of the serrations remains less at the higher strain rate, and never reaches the same magnitude attained at the normal strain rate. Portions of several higher strain rate curves are presented in Figure 5.

\section{Strain Hardening Calculations}

The data required for the computer calculation of strain hardening exponent include sample area, Young's modulus, Poisson's ratio, and load at various plastic strains. For all calculations, a value of $43 \times 10^{6}$ psi was used for Young's modulus, and 0.03 was used for Poisson's ratio. ${ }^{11}$

The computer program is quite versatile, and will perform several types of data plots in addition to calculating the strain hardening exponent and strength coefficient. Since both $n$ (strain hardening exponent) and $A$ (strength coefficient) are determined from a log true stress-log true strain curve, several of these plots were made to see how well the data conformed to a straight line. These plots revealed that for tests conducted at up to $650^{\circ} \mathrm{C}$, the log true stress-log true strain data are best described by two straight lines. The two lines can be determined by plotting low strain data and high strain data separately, as shown in Figures 6 and 7 .

Figure 6. Log True Stress-Log True Strain Plot for Sample Tested at Room Temperature.

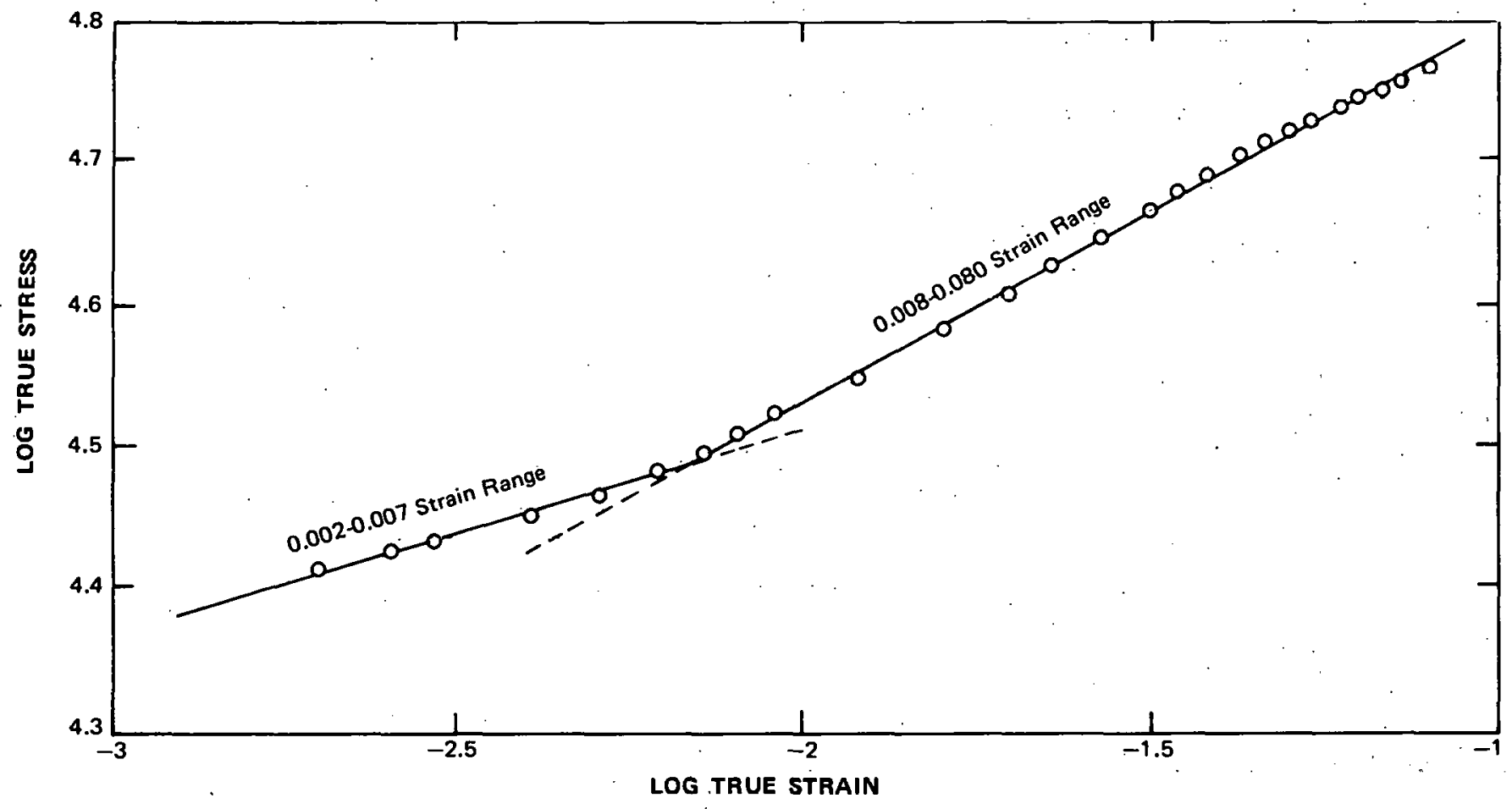




\section{RFP-1704}

For tests conducted in the temperature range from room temperature to $350^{\circ} \mathrm{C}, \mathrm{n}$ and $\mathrm{A}$ were calculated for the low-strain range 0.002 to 0.007 ; and for the high-strain range 0.008 to 0.080 . Figure 6 is the plot for a sample tested at room temperature, and shows a significant difference in slope between the low-strain points and the high-strain points.

The strain ranges for tests between 400 and $650^{\circ} \mathrm{C}$ were 0.002 to 0.012 , and 0.016 to 0.080 . Figure 7 , for a sample tested at $650^{\circ} \mathrm{C}$, is representative of samples tested in this temperature range. There is less difference in slope for the high-strain and low-strain ranges.

Above $650^{\circ} \mathrm{C}$ only one calculation was made, for the strain range 0.002 to 0.080 . As shown for $800^{\circ} \mathrm{C}$, Figure 8 , the whole strain range can be described by one line.

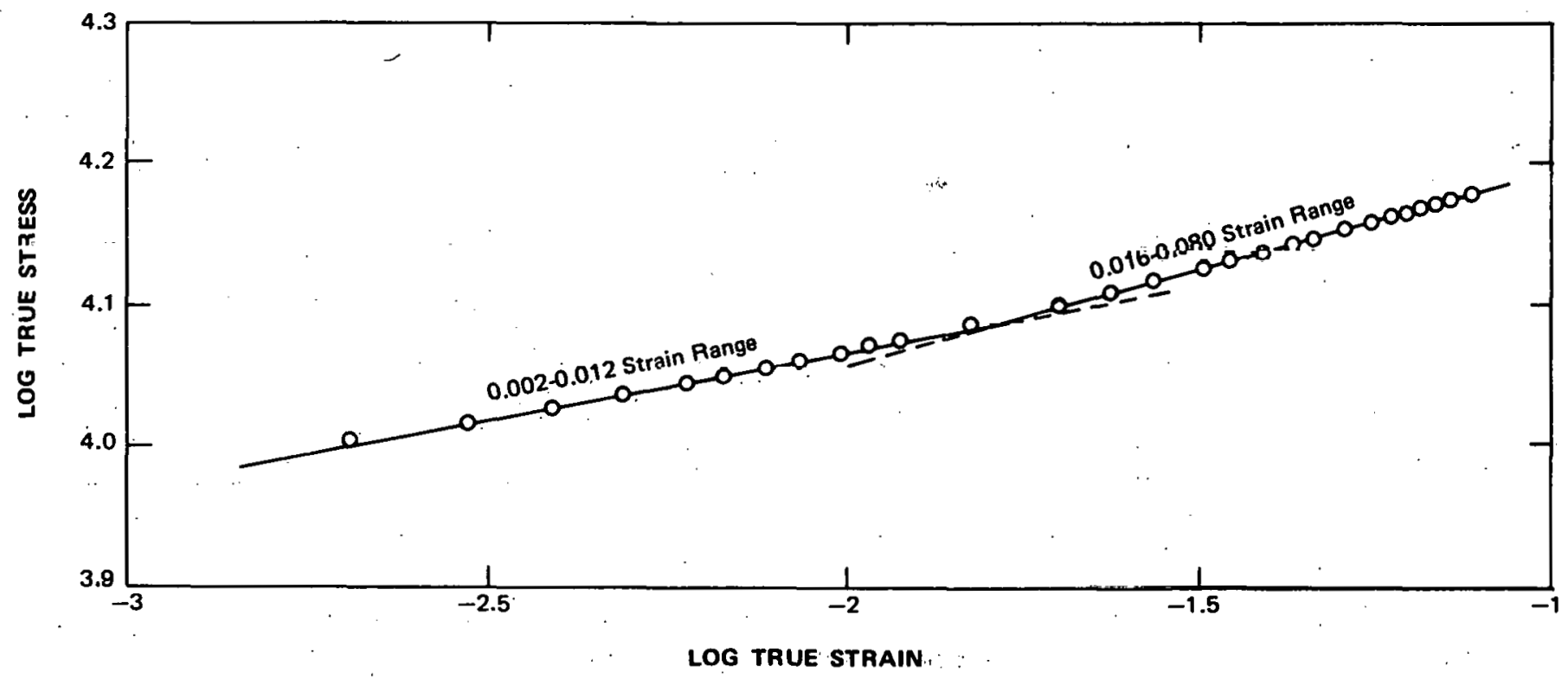

Figure 7. Log True Stress-Log True Strain:Plot for Sample Tested at $650^{\circ} \mathrm{C}$.

Figure 8. Log True Stress-Log True Strain Plot for Sample Tested at $800^{\circ} \mathrm{C}$.

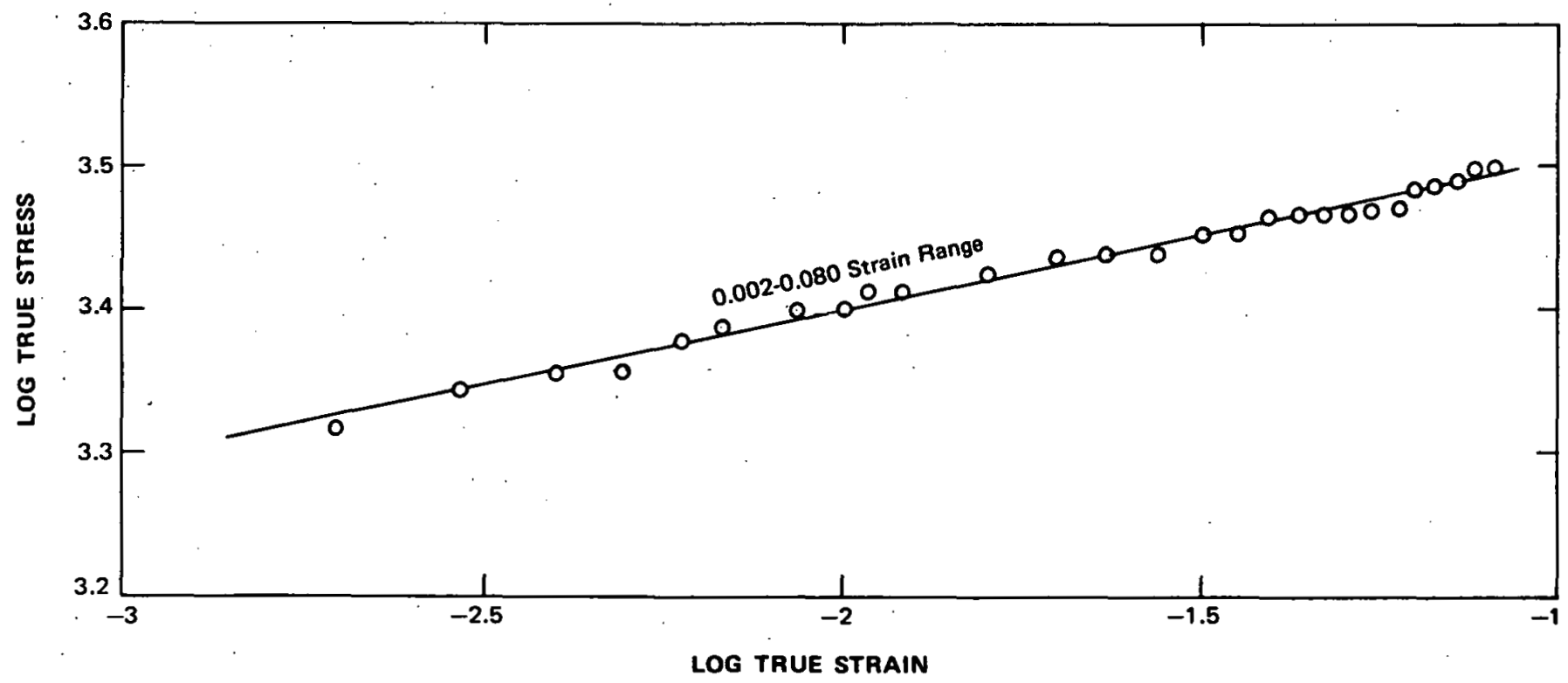


In picking the load and strain data off the curves, a strain increment of 0.001 was used for strains between 0.002 and 0.012 . Above 0.012 , strains were read at increments of 0.004 . At the highest temperatures, the straight-line fit is not as good, and the points appear to be in a stepped array.

The computer program also calculates an Index of Determination, which is a measure of how close the data points fit a straight line. An Index of 1 means a perfect straight-line fit. The scheme for calculating $\mathrm{n}$ and $\mathrm{A}$ described above resulted in an Index of Determination of over 0.99 for 62 of the 83 calculations made. This would indicate that the scheme used is a reasonable one. The close straight line fit confirms the use of the equation

$$
\mathrm{S}=A \mathrm{e}^{\mathrm{n}}
$$

to describe the plastic deformation behavior of bare-rolled ingot-sheet beryllium.

The strain hardening data for longitudinal specimens tested at the normal strain rate are tabulated in Table 4, and summarized graphically in Figures 9 and 10 . In most cases, these data are averages of 2 to 5 determinations, but a few data points reflect only one calculation.

\section{Metallographic Observations}

There was a noticeable difference in the contrast between grains on samples mounted flat (in the plane of the sheet), and samples mounted on edge (perpendicular to the plane of the sheet). This was apparently because the flat samples reveal grains with a predominantly basal plane orientation, and the edge samples exhibit more grains with prismatic or pyramidal orientations.

Four items of information were used to compare the metallographic appearance of samples tested at various temperatures. These were the fracture mode, grain deformation, cracking, and presence of voids. Metallographic observations will be correlated with the other properties later in the report.

At room temperature, the fracture mode is transgranular cleavage. There is also a significant amount of secondary cracking which branches off the main crack. Many cleavage cracks also are present away from the fracture area, primarily in the larger grains, and often oriented at $45^{\circ}$ to the stress axis. This material normally has an average grain size of about 40 microns, with occasional grains two-to-three times larger than that. However, the main cracks do not seem to favor propagation through the

Table 4. Constants for Calculating $S=A^{n}$ for Bare-Rolled Ingot-Sheet Beryllium at Various Temperatures.

\begin{tabular}{|c|c|c|c|c|c|c|}
\hline Test Temp & Low Strain Range & $A(p s i)$ & $\mathbf{n}$ & High Strain Range & $A$ (psi) & $\mathbf{n}$. \\
\hline Room Temperature & $0.002-0.007$ & 64,000 & 0.147 & $0.008-0.080$ & 112,000 & 0.257 \\
\hline 100 & $0.002-0: 007$ & 63,000 & 0.153 & $0.008-0.080$ & 85,500 & 0.213 \\
\hline 150 & $0.002-0.007$ & 61,000 & 0.169 & $0.008-0.080$ & 72,000 & 0.199 \\
\hline 200 & $0.002-0.007$ & 61,000 & 0.174 & $0.008-0.080$ & 69,000 & 0.196 \\
\hline 250 & $0.002-0.007$ & 46,500 & 0.149 & $0.008-0.080$ & 56,000 & 0.189 \\
\hline 300 & $0.002-0.007$ & 39,000 & 0.131 & $0.008-0.080$ & 47,000 & 0.172 \\
\hline 350 & $0.002-0.007$ & 33,500 & 0.125 & $0.008-0.080$ & - & - \\
\hline 400 & $0.002-0.012$ & 32,000 & 0.136 & $0.016-0.080$ & - & - \\
\hline 450 & $0.002-0.012$ & 31,000 & 0.134 & $0.0 .16-0.080$ & - . & - \\
\hline 500 & $0.002-0.012$ & 29,000 & 0.138 & $0.016-0.080$ & 32,000 & 0.157 \\
\hline 550 & $0.002-0.012$ & 26,500 & 0.120 & $0.016-0.080$ & 30,500 & 0.153 \\
\hline 600 & $0.002-0.012$ & 24,000 & 0.110 & $0.016-0.080$ & 32,000 & 0.172 \\
\hline 650 & $0.002-0.012$ & 18,500 & 0.099 & $0.016-0.080$ & 21,500 & 0.136 \\
\hline 700 & - & - & - & $0.002-0.080$ & 12,000 & 0.104 \\
\hline 750 & - & - & - & $0.002-0.080$ & 6,500 & 0.093 \\
\hline 800 & - & - & - & $0.002-0.080$ & 4,500 & 0.091 \\
\hline
\end{tabular}


RFP-1704

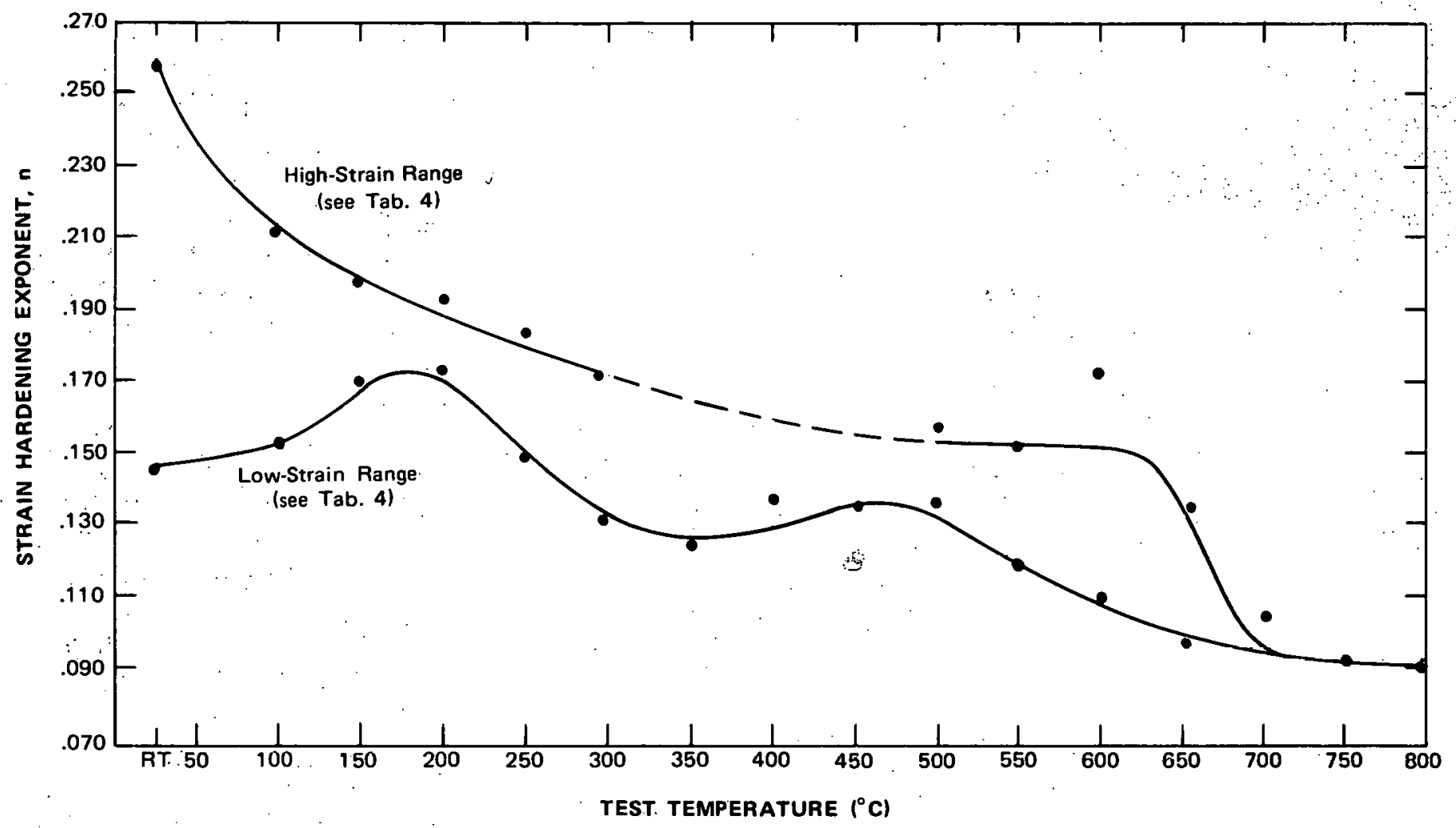

Figure 9. Effect of Test Temperature on Strain Hardening Exponent for Bare-Rolled Ingot-Sheet Beryllium $\left(n\right.$ in $\left.S=A e^{n}\right)$.

Figure 10. Effect of Test Temperature on Strength Coefficient for Bare-Rolled Ingot-Sheet Beryllium $\left(A\right.$ in $\left.S=A e^{n}\right)$ :

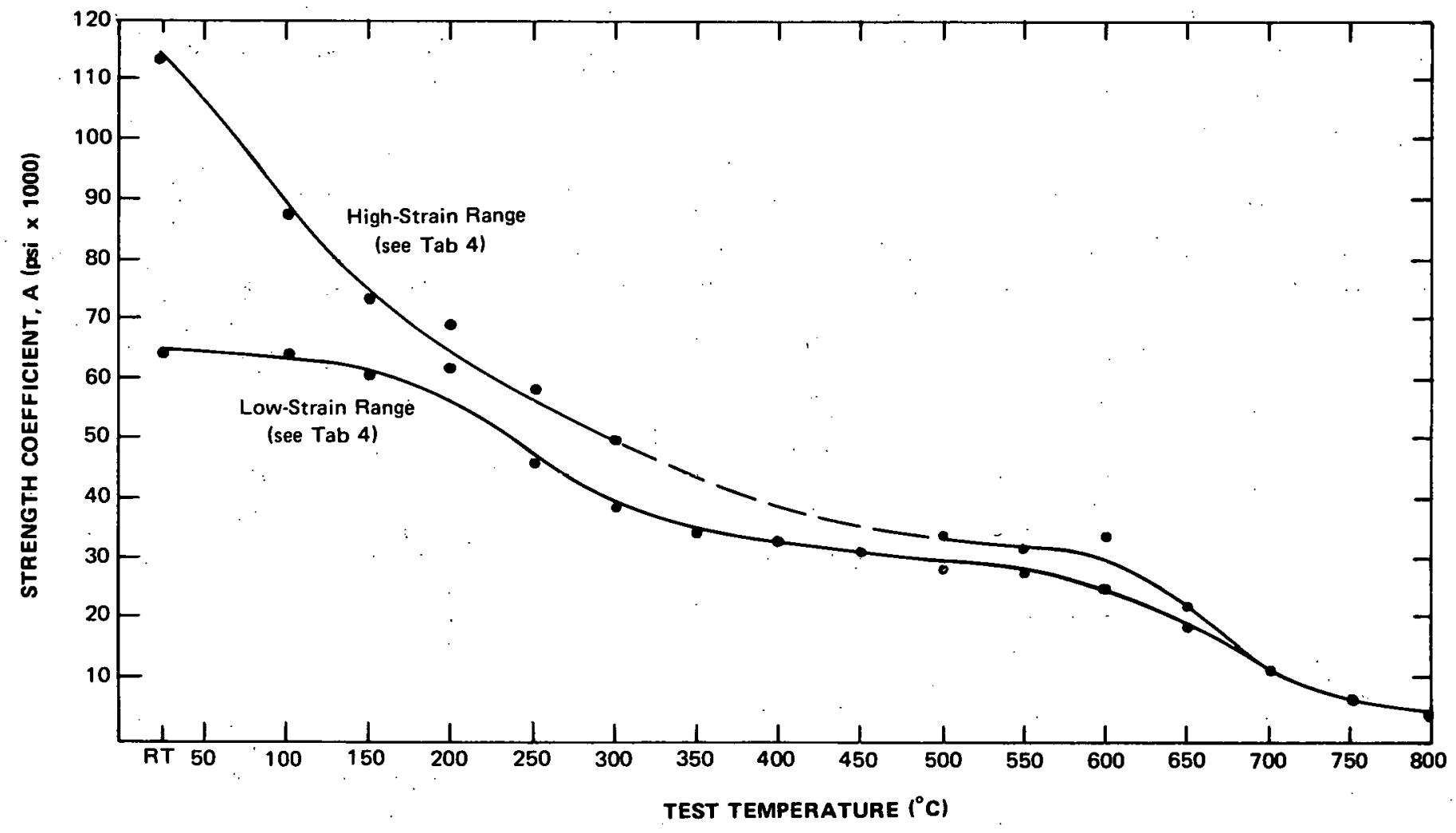


large grains, so they apparently do not significantly affect the fracture. There is no obvious grain deformation prior to fracture, and no voids in any of the samples examined. A portion of a roomtemperature fracture surface is shown in Figure 11.

Figure 12 is representative of the fracture appearance of specimens tested at $300^{\circ} \mathrm{C}$, the first elongation peak. The fracture mode is transgranular cleavage, but severe grain deformation occurred prior to fracture. Numerous secondary cleavage cracks are visible near the fracture, but these cracks are not found away from the immediate fracture area. Although grain deformation is most severe adjacent to the fracture, it is not confined to the fracture area. Significant deformation is present over the entire specimen test length. The $300^{\circ} \mathrm{C}$ specimens also show some voids, with the heaviest concentration near the fracture.

A specimen tested at $400^{\circ} \mathrm{C}$ is shown in Figure 13 . Severe grain deformation prior to cleavage fracture is apparent. This deformation is even more pronounced than that shown for the $300^{\circ}$ specimen. There are also a very few small, secondary cleavage cracks off the main crack, but they are rather insignificant. No cracks were found away from the immediate fracture area, and grain deformation was much less but still evident. Very prominent voids are present in this sample. They appear definitely to be the result of the tensile deformation. Only a few, smaller voids were found away from the fracture area.

Necking at $500^{\circ} \mathrm{C}$ is evidenced by the elongation minimum and the reduction-in-area maximum. At this temperature, the fracture mode is no longer cleavage. As shown in Figure 14, the fracture surface is very irregular, and the mode appears to be transgranular and ductile. Severe grain deformation is evident adjacent to the fracture. The severity of deformation decreases away from the fracture area, and is not significant at the end of the test section. No cracks are visible either at the fracture or away from it. Some voids are present, concentrated near the fracture, but their size and number are not as great as they were at 300 and $400^{\circ} \mathrm{C}$.

Figure 15 shows a portion of the fracture surface of a specimen tested at $700^{\circ} \mathrm{C}$. This corresponds to the second elongation peak. The fracture mode appears to be a combination of transgranular and intergranular, with the transgranular areas having a ductile appearance. There is obvious grain deformation, but not as severe as that shown at the lower

Figure 11. Appearance of Fracture Surface of Specimen Tested at Room Temperature. 100X, Polarized Light.

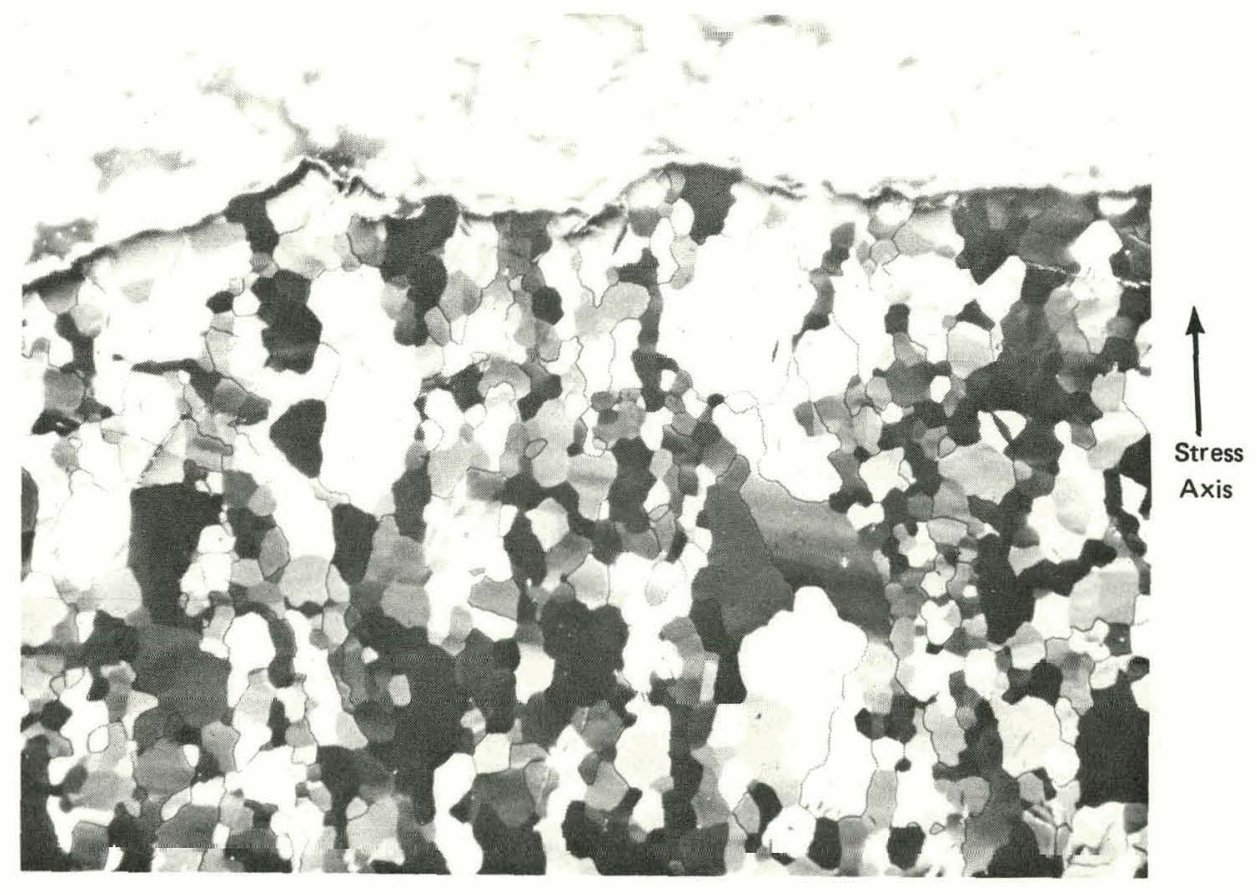


RFP-1704

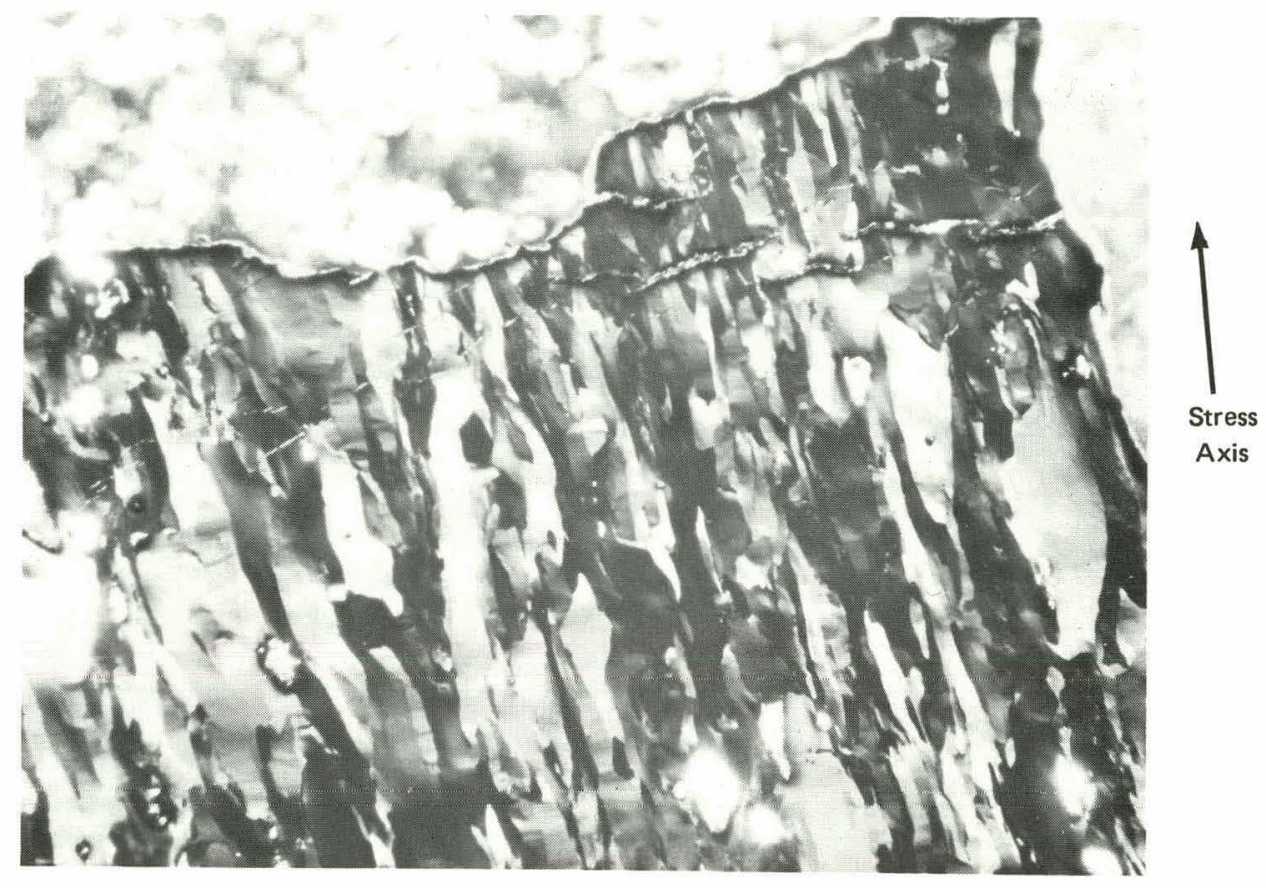

Figure 12. Appearance of Fracture Surface of Specimen Tested at $300^{\circ} \mathrm{C} .100 \mathrm{X}$, Polarized Light.

Figure 13. Appearance of Fracture Surface of Specimen Tested at $400^{\circ} \mathrm{C} .100 \mathrm{X}$, Polarized Light.

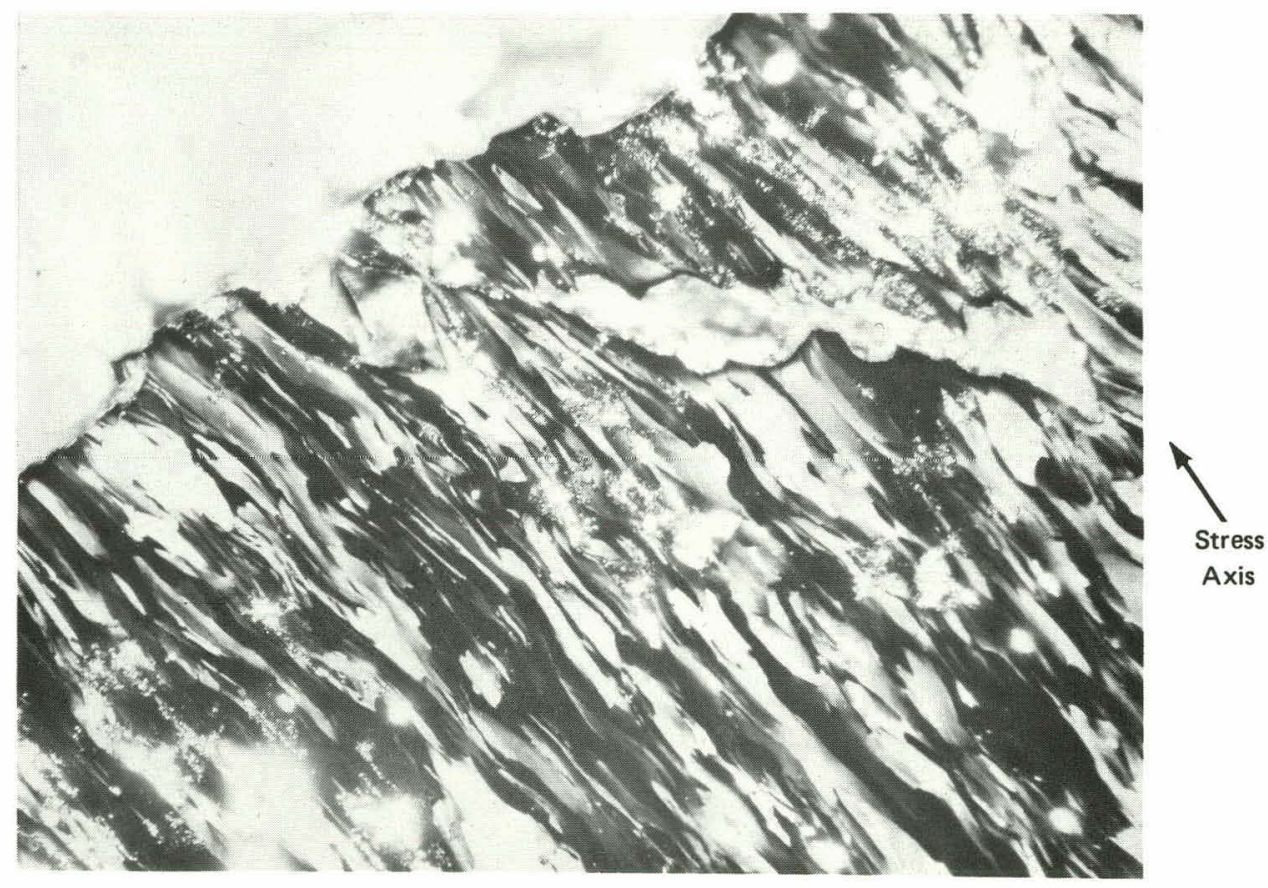




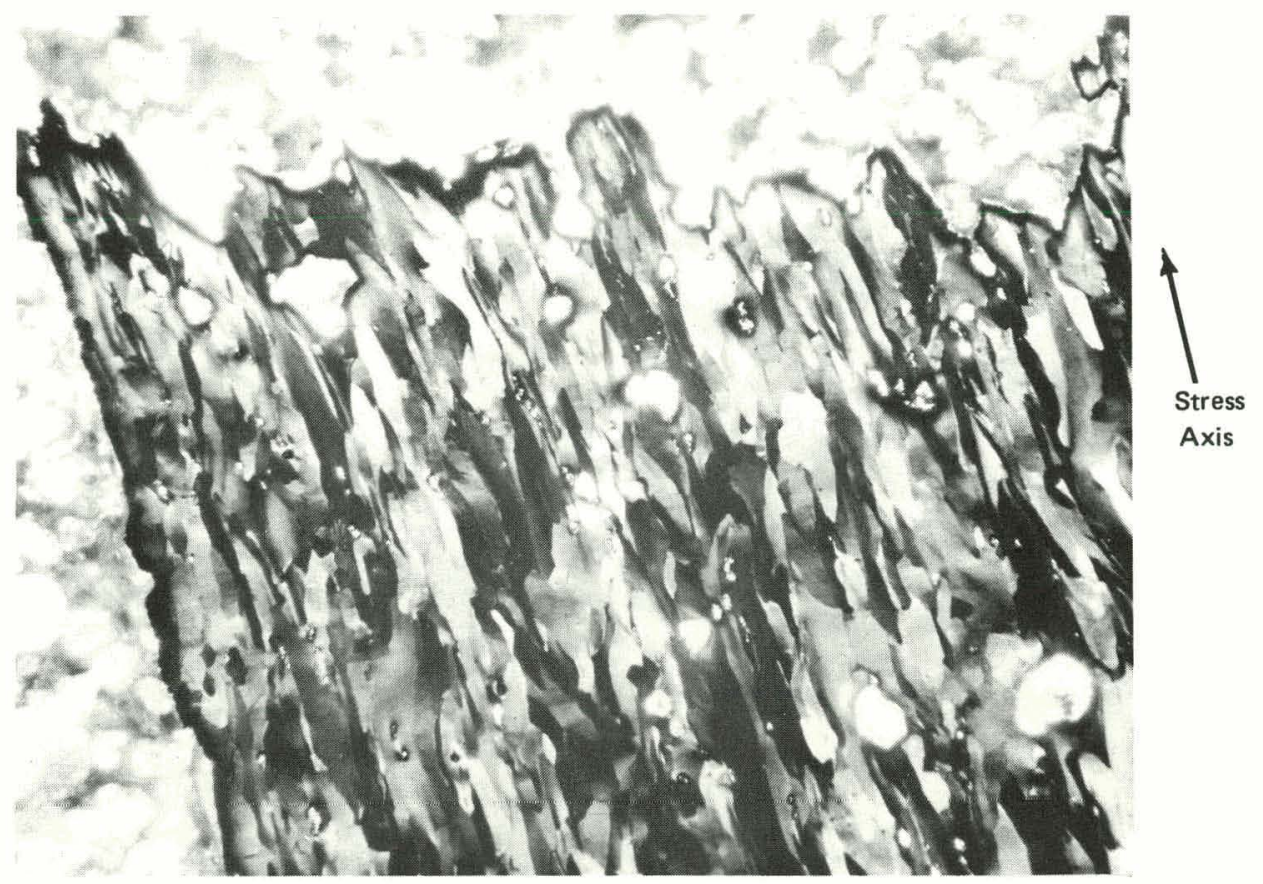

Figure 14. Appearance of Fracture Surface of Specimen Tested at $500^{\circ} \mathrm{C} .100 \mathrm{X}$, Polarized Light.

Figure 15. Appearance of Fracture Surface of Specimen Tested at $700^{\circ} \mathrm{C} .100 \mathrm{X}$, Polarized Light.

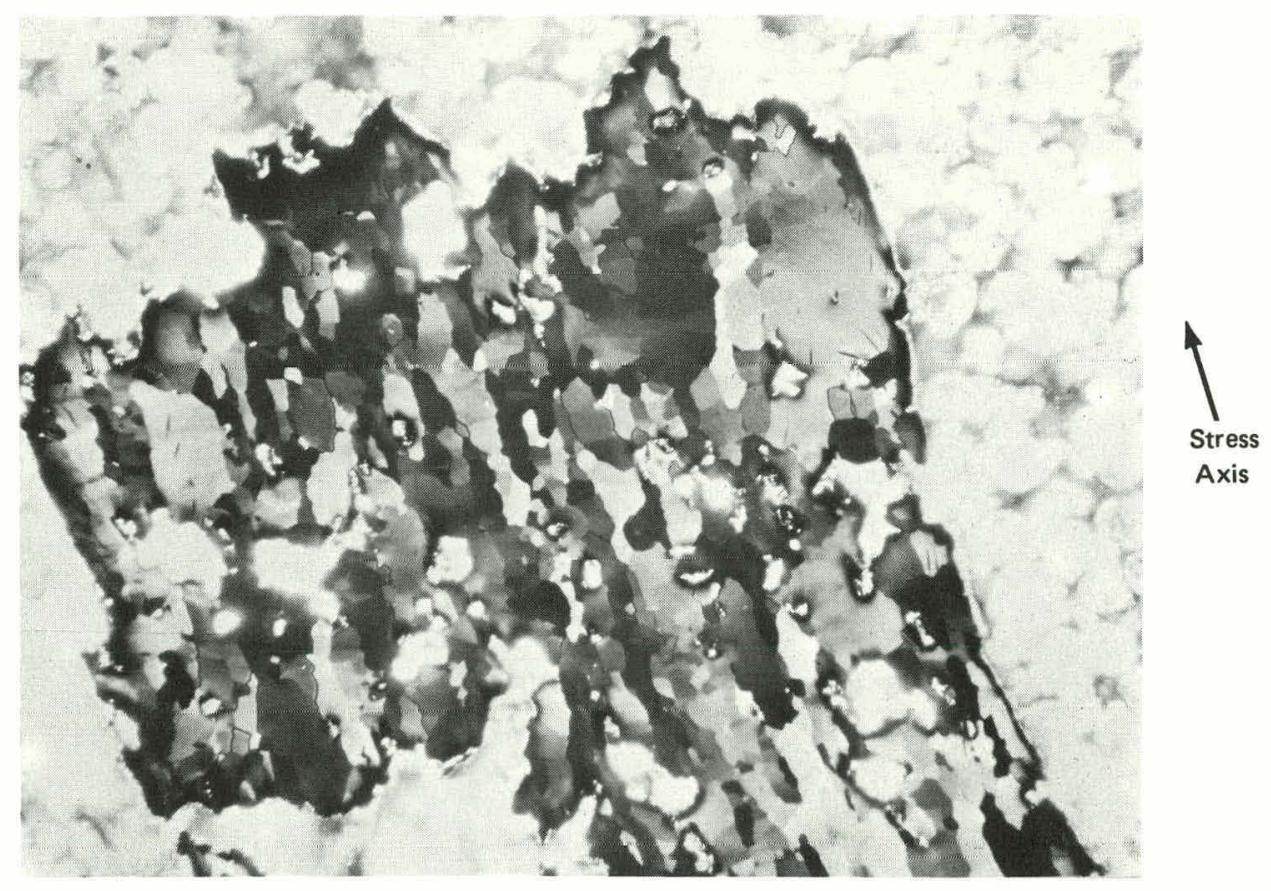


temperatures (Figures 12 through 14). Away from the fracture area, the grain deformation is reduced, but still evident. No cleavage cracks were found, but several areas may have shown slight grain boundary cracking. Voids are present both near the fracture and away from the fracture. Many of these voids look like single grains or groups of grains which were removed, presumably caused by a change in fracture mode to include some intergranular failure.

At $800^{\circ} \mathrm{C}$ (Figure 16) the fracture mode is primarily intergranular, and individual grains are clearly visible on the fracture surface. Deformed grains as such are not prominent, but it is evident that recrystallization and grain growth have occurred. Most of the grains are equiaxed, and are much larger than the original grains (Figure 11). The new grains away from the fracture area do not show as much growth as the grains near the fracture area, indicating less deformation there than at the fracture. Some intergranular cracking was found near the fracture. A significant number of voids are present throughout the sample, with the highest concentration near the fracture. These voids appear to be the result of whole grains being pulled out owing to weakening of the grain boundaries.
There were no significant differences in fracture appearances of the samples tested at the higher strain rate, as compared to the lower strain rate tests. The changes in fracture mode did occur at higher temperatures, corresponding to the changes in tensile properties.

\section{DISCUSSION OF RESULTS}

The tensile properties of Rocky Flats ingot-sheet beryllium reported in Reference 4 indicate this material is of consistent quality from sheet to sheet. The present investigation also demonstrates the uniformity of this product within a given sheet. A substantial number of room temperature tests were conducted on specimens from variuus locations within the sheet, and standard deviations of less than 1.0 resulted when these data were averaged. Even at elevated temperatures, four duplicate tests normally produced almost identical results.

Preliminary statistical data on S-200 hot-pressed block $^{12}$ appear to show greater variation in properties, especially yield strength, than does the Rocky Flats ingot-sheet. Elevated temperature results on cast-and-extruded material show considerable scatter in the ductility data. ${ }^{13}$

Figure 16. Appearance of Fracture Surface of Specimen Tested at $800^{\circ} \mathrm{C} .100 \mathrm{X}$, Polarized Light.

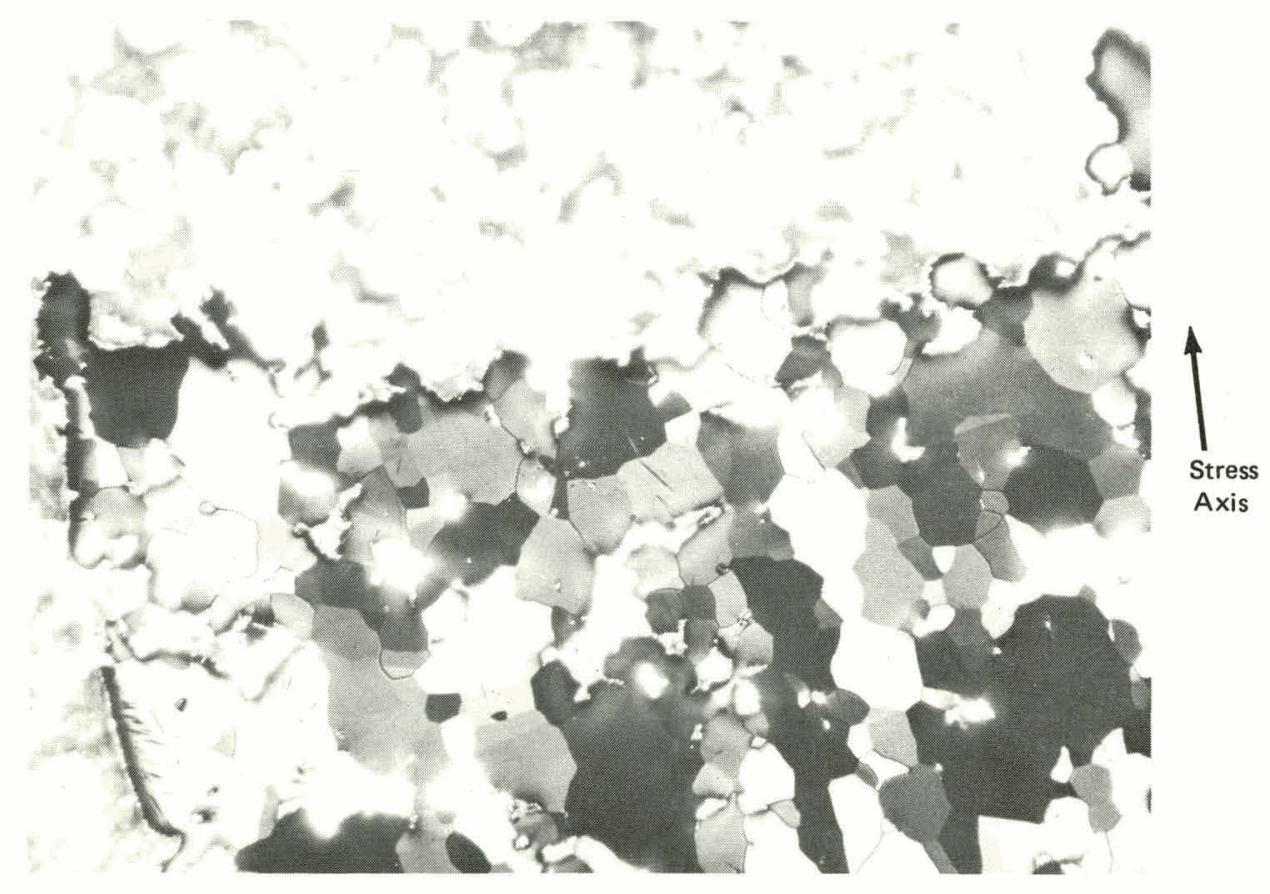


These differences in uniformity between various grades of beryllium are presumable owing to fabrication history, and tend to indicate that bare-rolled ingot-sheet is inherently more uniform than lessworked grades of beryllium.

The steady drop in yield and ultimate strength of ingot-sheet, tested above room temperature, is similar to the behavior generally reported for most grades of beryllium. ${ }^{12-21}$ However, some vacuum hot-pressed block material has shown a slight increase in yield strength above room temperature in about the 150 to $250^{\circ} \mathrm{C}$ range. ${ }^{22}$

Plots of tensile elongation versus test temperature for various grades of beryllium normally show a maximum in the range of 200 to $600^{\circ} \mathrm{C}^{3,12-21}$ For bare-rolled ingot-sheet, this maximum occurs at $300^{\circ} \mathrm{C}$, and is generally higher than the maximum reported for various grades of powder product. ${ }^{12,14,16,18,20,21}$ In general, the vacuum cast grades seem to show greater high-temperature ductility than the powder-source material.

Some investigators ${ }^{3}, 12,13,15,16,18,21$ also report a minimum in the elongation versus temperature curves anywhere from about 450 to $900^{\circ} \mathrm{C}$. For powder material, these minima drop to $10 \%$ or less; but for bare-rolled ingot-sheet at $500^{\circ} \mathrm{C}$, the elongation minimum is $35 \%$.

The presence of a second peak in the elongation curve has been shown for cast material, ${ }^{3,13}$ and may also be indicated for some powder-source material. ${ }^{12,16}$ The ingot-sheet material used in this investigation exhibited a second elongation peak near $80 \%$ at about $700^{\circ} \mathrm{C}$.

The previous discussions, which compare elongation versus test temperature curves for several grades of beryllium, disclose that bare-rolled ingot-sheet material exhibits better high-temperature ductility than most (possibly all) other grades of beryllium. This could have significant implications in regard to fabrication practices.

Many investigators report drastic changes in tensile elongation at elevated temperatures; some have considered these changes to indicate a typical brittle-ductile transition. ${ }^{15,19,23}$ Allan and Moore ${ }^{19}$ attempted to relate this behavior to grain size and strain rate dependence, and concluded that constitutional effects and bend-plane activity were also important. In Reference 20 , a theory of thermally activated cross slip of screw dislocations from basal planes to pyramidal and prism planes is proposed to explain the elongation changes.

Other workers feel that the ductility behavior is related to impurities and precipitation aging reactions. ${ }^{16-18,24,25}$ The impurities which have the most affect are $\mathrm{BeO}, \mathrm{Fe}$, and $\mathrm{Al}$. Beaver and Wikle ${ }^{21}$ proposed grain size as the major factor affecting mechanical properties, but as discussed, other variables are also significant.

The elevated-temperature ductility behavior of bare-rolled ingot-sheet beryllium appears to be strongly influenced by impurities. Moore et al., ${ }^{17}$ and Gelles and Peterson ${ }^{22}$ have related hightemperature brittleness to material which is in a "solutionized" condition; iron being the important solute atom. The precipitation behavior of barerolled ingot-sheet beryllium has been investigated by Fraikor and his co-workers. ${ }^{26,27}$. From these studies it was found that after final rolling and heat treatment, this material is in an aged condition that removes iron from solid solution as either $\mathrm{FeBe}_{11}$ or $\mathrm{AlFeBe}_{4}$. The ternary precipitate normally predominates. The removal of iron from solid solution presumably helps to improve the high-temperature ductility of this material.

It is also reported that impurity particles, probably $\mathrm{BeO}$, can initiate both intergranular and transgranular fractures. ${ }^{16}$ The material used in this investigation did have a low $\mathrm{BeO}$ content; therefore, this would appear to be another factor contributing to good ductility at elevated temperatures.

The presence of the peaks in the elongation curves generally coincides with changes in fracture mode. However; different grades of beryllium reportedly differ somewhat in fracture appearance. Most investigators found cleavage failure at the lower temperatures and intergranular failure at the higher temperatures. ${ }^{13,16,18,22}$ Several investigators reported ductile rupture at some temperature range between that for cleavage and that for intergranular failure. ${ }^{15,17,18,22}$ Twinning at low temperatures was also reported. ${ }^{13,16,18}$ 
In the present investigation there appears to be no significant involvement of twinning in the fracture process. Only a very few twins were observed, and almost all appeared to result from metallographic preparation. The initial increase in elongation above room temperature is attributed to the reduced critical resolved shear stress for prism slip. ${ }^{28}$ It has also been disclosed that as the contribution from prism slip increases, a greater relaxation of stress concentrations occurs, and ductility is further enhanced. ${ }^{22}$ This can be seen in the microstructure as severe grain deformation.

The voids which were noted at $300^{\circ} \mathrm{C}$ and above are said to promote intergranular fracture; thereby causing the drop in elongation. ${ }^{16}$ At $500^{\circ} \mathrm{C}$, the elongation minimum, coalescence of voids is predominent, and the fracture is essentially ductile rupture. At this point, the critical resolved shear stress for basal and prism flow apparently become equal.

With increasing temperature, elongation increases. to a second peak. Metallographic examination shows a greater influence of grain boundary effects. Gelles and Peterson point out that grain boundary separation causes an artificially high elongation. ${ }^{22}$ Reduction in area values therefore provide a truer measure of ductility.

Above the second elongation peak, the failure mode is predominantly intergranular, and recrystallization and grain growth are evident:

From the values reported here, the strain hardening behavior of bare-rolled ingot-sheet beryllium would be comparable to that of some steels; for example, the beryllium should exhibit less strain hardening than copper alloys. ${ }^{9}$ Also, the use of two lines to more accurately describe the log true stress-log true strain plots is not uncommon. ${ }^{7}$

Serrated stress-strain curves, or repeated yielding, have been reported by other investigators for both ingot-source and powder-source beryllium. ${ }^{3,18}$ This phenomenon is usually attributed to dynamic strain aging.

\section{CONCLUSIONS}

From the results of this investigation, the following conclusions may be drawn.
1. Rocky Flats bare-rolled ingot-sheet beryllium exhibits uniform properties throughout a given sheet.

2. The plot of tensile elongation versus test temperature shows a double peak. Above room temperature all elongations are greater than 15 percent.

3. The high-temperature ductility of this material appears to be a result of low $\mathrm{BeO}$ content and post-rolling heat treatment.

4. Bare-rolled ingot-sheet beryllium exhibits serrated load-strain curves when tested above $400^{\circ} \mathrm{C}$.

5. The plastic deformation behavior may be approximated by the equation $S=A e^{n}$. The strain hardening exponent, $n$, varies between about 0.10 and 0.26 , depending on strain and test temperature.

6. A ten-fold increase in testing speed shifts the plots of tensile properties versus test temperature to higher temperatures:

7. With increasing test temperature, the fracture mode goes from cleavage, to ductile, to intergranular.

\section{REFERENCES}

1. J. L. Frankeny and D. R. Floyd;:" Ingot-Sheet Beryl= lium Fabrication," USAEC RFP-910, Rocky Flats Division, Dow Chemical U.S.A., Golden, Colorado, Fébruary 9, 1968.

2. S. Beitscher, "Tensile Properties of Rocky Flats Division Ingot-Sheet Beryllium from Room Temperature to $250^{\circ} \mathrm{C}$," USAEC RFP-1205, Rocky Flats Division, Dow Chemical U.S.A., Golden, Colorado, December 11, 1968.

3. S. Beitscher, "Tensile Properties of Rocky Flats Division Ingot-Sheet Beryllium from -196 to $700^{\circ} \mathrm{C}$," USAEC RFP-1 194, Rocky Flats Division, Dow Chemical U.S.A., Golden, Colorado, 1970.

4. D. V. Miley, and R.P. Brugger, "Tensile Properties of Hot-Formed Ingot-Sheet Beryllium," USAEC RFP-1525, Rocky Flats Division, Dow Chemical U.S.A., Golden, Colorado, April 12, 1970.

5. D. V. Miley, "Bending Fatigue of Ingot-Source Sheet Beryllium," USAEC RFP-1534, Rocky Flats Division, Dow Chemical U.S.A., Golden, Colorado, 1970. 
6. Materials Advisory Board, Evaluation Test Methods for Beryllium, MAB-205-M, National Academy of Sciences, National Research Council, Washington, D. C., 1966.

7. G. E. Dieter, Jr., Mechanical Metallurgy, 1961, McGraw-Hill, New York, N. Y., p 247-248.

8. S. Beitscher and J. H. Doyle, "A Computer Program to Evaluate Strain Hardening Exponent (SEX), USAEC RFP-1759, Rocky Flats Division, Dow Chemical U.S.A., Golden, Colorado, September 6, 1972.

9. A. E. Calabra and D. V. Miley, "A Vacuum Potting Technique for Metallographic Specimens Using Black Epoxy Resin and Black Alumina Filler," USAEC RFP-1813, Rocky Flats Division, Dow Chemical U.S.A., Golden, Colorado, August 15, 1972.

10. A. E. Calabra and R. J. Jackson, "Metallographic Techniques for Vacuum -Cast Rolled Ingot Beryllium Sheet," USAEC RFP-962, Rocky Flats Division, Dow Chemical U.S.A., Golden, Colorado, August 7, 1967.

11. H. H. Hausner, The Beryllium Metal Handbook, General Astrometals Corporation, Yonkers, New York, February 1967, p 19.

12. H. H. Hausner, Beryllium: Its Metallurgy and Properties, 1965, University of California Press, Berkely, California, p 216-228.

13. G. E. Darwin and J. H. Buddery, Beryllium, 1960, Academic Press, New York, N. Y., p 187-189.

14. D.W. White, Jr., and J. E. Burke, The Metal Beryllium, 1955, American Society for Metals, Clevelend, Ohio. p 196-198.

15. J.E. J. Bunce and R. E. Evans, "A study of the Effect of Grain Size, Texture, and Annealing Treatment on the Properties of Wrought Beryllium Ingot," The Metallurgy of Beryllium, 1963, The Institute of Metals, London, p 246-263.

16. M. I. Jacobson and F. M. Almeter, "Tensile Failure of QMV Beryllium from Room Temperature to $870^{\circ} \mathrm{C}$," The Metallurgy of Beryllium, 1963, The Institute of Metals, London, p 98-111.

17. A. Moore, F. Morrow, V. D. Scott, and D. A. Cheer, "Precipitation Aging and Improved Mechanical Properties in Commercially Pure Beryllium and Beryllium Alloys," The Metallurgy of Beryllium, 1963, The Institute of Metals, London, p 112-136.
18. G. C. E. Olds, T. Raine, J. A. Robinson, and A. G. Todd, "High-Temperature Ductility of Powder-Fabricated Beryllium at High and Low Strain Rates," The Metallurgy of Beryllium, 1963, The Institute of Metals, London, p 166-176.

19. B. Allen and A. Moore, "The Ductile-Brittle Transition in Beryllium," Metallurgy of Beryllium, 1963, The Institute of Metals, London, p 193-206.

20. Air Force Materials Laboratory, Metallurgical Factors Affecting the Ductile-Brittle Transition in Beryllium, ASD-TDR-62-509, Vol. V, Wright-Patterson Air Force Base, Ohio, February 1965.

21. W. W. Beaver and K. G. Wikle, "Mechanical Properties of Beryllium Fabricated by Powder Metallurgy," Journal of Metals, May 1954, p 559-573.

22. S. H. Gelles and J. H. Peterson, "Characteristics of Commercial Vacuum-Hot-Pressed Beryllium,” BMI-X-629, Battelle Columbus Laboratories, Columbus, Ohio, 1972.

23. P. Cotterill, R. E. Goosey, and A. J. Martin, "An Evaluation of the Hydrogen Content of Commercially Pure Beryllium and Its Effect Upon the Ductile-toBrittle Transition Temperature," The Metallurgy of Beryllium, 1963, The Institute of Metals, London, p 220-236.

24. K. D. Sinelnikov, V. E. Ivanov, V. M. Amonenko, and G. F. Tikhinsky, "Some Properties of High-Purity Distilled Beryllium," The Metallurgy of Beryllium, 1963, The Institute of Metals, London, p 264-272.

25. Air Force Materials Laboratory, Identification of Inclusions and Precipitates in Beryllium of Different Origins, ASD-TDR-62-509, Vol. VII, Wright-Patterson Air Force Base, Ohio, February 1965.

26 F. J. Fraikor, V. K. Grotzky, A. W. Brewer, and H. E. Reed, "Precipitation Characteristics of Rocky Flats Beryllium Ingot Sheet," USAEC RFP-1041, Rocky Flats Division, Dow Chemical U.S.A., Golden, Colorado, March 12, 1968.

27. F. J. Fraikor and A. W. Brewer, "Precipitation in Quenched and Aged Beryllium Ingot Sheet," Trans. $A S M, 16,1968, \mathrm{p} 784-789$.

28. H. D. Hanes, S. W. Proembka, J. B. Melehan, and P. J. Gripshover, "Physical Metallurgy of Beryllium," DMIC Report 230, Battelle Mcmorial Institute, Columbus, Ohio, June 24, 1966. 